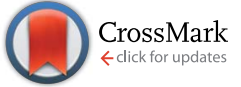

Cite this: RSC Adv., 2016, 6, 24273

Received 19th November 2015 Accepted 24th February 2016

DOI: $10.1039 / c 5 r a 24563 j$

www.rsc.org/advances

\section{Novel non-hydrolytic templated sol-gel synthesis of mesoporous aluminosilicates and their use as aminolysis catalysts $\uparrow$}

\author{
David Skoda, ${ }^{\text {ab }}$ Ales Styskalik, ${ }^{\text {ab }}$ Zdenek Moravec, ${ }^{a}$ Petr Bezdicka, ${ }^{c}$ Michal Babiak, ${ }^{\text {ab }}$ \\ Mariana Klementova, ${ }^{c}$ Craig E. Barnes ${ }^{d}$ and Jiri Pinkas ${ }^{\star a b}$ \\ A novel non-hydrolytic sol-gel (NHSG) synthesis of mesoporous aluminosilicate xerogels is presented. The \\ polycondensation between silicon acetate, $\mathrm{Si}(\mathrm{OAc})_{4}$, and tris(dimethylamido)alane, $\mathrm{Al}\left(\mathrm{NMe}_{2}\right)_{3}$, leads to \\ homogeneous aluminosilicate xerogels containing $\mathrm{Si}-\mathrm{O}-\mathrm{Al}$ linkages through dimethylacetamide \\ elimination. The addition of Pluronic P123 and F127 templates provides stiff gels that are, after \\ calcination at $500{ }^{\circ} \mathrm{C}$, converted to stable mesoporous xerogels with a high surface area $\left(>600 \mathrm{~m}^{2} \mathrm{~g}^{-1}\right)$ \\ and wormhole-type pores $(d=5.9 \mathrm{~nm})$. The xerogels exhibit high catalytic activity in aminolysis of \\ styrene oxide ( $82 \%$ conversion) with the turnover frequency up to 100.
}

\section{Introduction}

Aluminosilicate zeolites with their uniform molecular-sized pores, high surface acidity, and large number of active sites have been extensively applied as molecular sieves, ion exchangers, and solid acid catalysts in industrial catalytic processes since the last century. ${ }^{\mathbf{1 , 2}}$ They are usually prepared from alkoxide precursors under hydrothermal conditions by socalled molecular templating wherein a cationic organic species acts as a template for the formation of ordered pores and channels. This approach generates highly ordered microporous materials whose pore diameters are controlled by the size of the molecular templates. The pore sizes of zeolites are therefore below $15 \AA$ and typically $4-10 \AA .^{3}$ However, the conversion or adsorption of bulky organic molecules requires large pore channels $(>2 \mathrm{~nm})$, which has not been achieved in stable microporous zeolites. A synthetic challenge in this context is the disparate hydrolysis rates of $\mathrm{Si}$ and $\mathrm{Al}$ alkoxides which lead to precipitation of alumina rich phases and has to be prevented by prehydrolysis ${ }^{4}$ or chelation methods. ${ }^{5}$ The discovery of ordered mesoporous silicates, such as MCM-41, with high surface areas, well-defined and tunable pore diameters from 1.5 to $10 \mathrm{~nm}$ was a significant advancement in this field. The catalysts with the

${ }^{a}$ Department of Chemistry, Masaryk University, Kotlarska 2, CZ-61137 Brno, Czech Republic. E-mail:jpinkas@chemi.muni.cz

${ }^{b}$ CEITEC MU, Masaryk University, Kamenice 5, CZ-62500 Brno, Czech Republic

'Institute of Inorganic Chemistry of the ASCR, v.v.i., CZ-25068 Husinec-Rez, Czech Republic

${ }^{d}$ Department of Chemistry, University of Tennessee, Knoxville, TN 37996-1600, USA $\dagger$ Electronic supplementary information (ESI) available. CCDC 1437252. For ESI and crystallographic data in CIF or other electronic format see DOI: $10.1039 / \mathrm{c} 5 \mathrm{ra} 24563 \mathrm{j}$ hexagonal structure, such as Al-MCM-41, offered an opportunity for processing bulky molecules ${ }^{6}$ and attracted much interest. ${ }^{7}$ Unfortunately, the poor hydrothermal stability of the MCM-41-type materials restricts their wider applications in industrial catalysis. Nevertheless, improved hydrothermal stability of cubic Al-MCM-48 materials was achieved by supercritical fluid (SCF) impregnation. ${ }^{8}$ Increase of hydrothermal stability was achieved also by 2-D hexagonal mesoporous SBA15 materials $^{9}$ with large pores $(4.6-30 \mathrm{~nm})$, thick pore walls (3.1-6.4 nm), and high specific surface areas (up to 1000 $\left.\mathrm{m}^{2} \mathrm{~g}^{-1}\right)$. However, electrically neutral frameworks of silica SBA15 materials exhibit very weak acidity derived from the silanol groups located on the pore walls. Therefore, much effort have been devoted to increasing the acidity by introduction of $\mathrm{Al}$ into the framework by direct synthesis, ${ }^{\mathbf{1 0}}$ post-synthesis ${ }^{\mathbf{1 1}}$ and grafting or impregnation ${ }^{\mathbf{1 2}}$ strategies. The procedure of direct synthesis is relatively simple, but only a small number of the heteroatoms can be introduced into the mesophases. By contrast, the procedure of grafting or impregnation is complicated and difficult to replicate. Moreover, there are always more 6-coordinated $\mathrm{Al}$ atoms in these materials than 4-coordinated ones which are essential for Brønsted acidity. ${ }^{13}$ Al-SBA-15 materials with a large number of moderate acidic sites are very promising catalysts and supports allowing catalytic cracking, alkylation, and hydrotreating reactions. ${ }^{\mathbf{1 4 1 5}}$ The preparation of Al-SBA-15 via the post-synthesis method was reported by $\mathrm{Li}^{\mathbf{1 6}}$ by treatment with aluminum isopropoxide. Han reported well-ordered hexagonal mesoporous aluminosilicates synthesized by the re-crystallization of SBA-15 in a dilute solution of aluminosilicate sol, glycerol, or both. ${ }^{17}$ Recently, the assembly of zeolite seeds or coating of walls of mesoporous matrices (SBA-15, MCM-48) with zeolites was described as a promising way to novel class of hydrothermally stable 
mesoporous aluminosilicate catalysts. The assembly of ZSM-5, beta, TS-1, and FAU zeolite seeds was achieved with the use of structure-directing agents, such as cetyltrimethyl ammonium bromide (CTAB) or Pluronic P123. ${ }^{18-21}$ A so-called coated route approach using a dilute clear solution of primary zeolite units was employed to synthesize ultrastable mesoporous aluminosilicate molecular sieves. ${ }^{22,23}$ This method produces a new type of nanocrystalline zeolitic material with mesopore walls formed by a templated solid-state secondary crystallization of zeolites into walls of SBA- 15 .

Recently, Liu ${ }^{13}$ has obtained Al-rich mesoporous aluminosilicates with improved hydrothermal stability by assembling zeolite $\mathrm{Y}$ and beta precursors in the walls of mesophases. For example, the retaining ratio of the total surface area was 33\% after hydrothermal treatment in $100 \%$ water vapor at $800{ }^{\circ} \mathrm{C}$ for $15 \mathrm{~h}$. This group also reported a pH-adjusting method ${ }^{24}$ based on the assembly of beta zeolite. An approach recently published by Enterría ${ }^{25}$ provides a simple strategy based on the overgrowing mesoporous silica (MCM-48) on crystalline zeolite particles. For this purpose, preformed zeolite is added to mesoporous silica gel, which results in materials with a microporous zeolitic core and a mesoporous silica cover (MCM-48).

The methods and procedures mentioned above all involve hydrolytic reactions. Aluminosilicates can also be successfully prepared by non-hydrolytic routes. With these methods, it is possible to overcome the problems of different hydrolysis rates and subsequent phase separation. These techniques allow reaction control on atomic scale and homogeneous dispersions of silicon and aluminum atoms in the gel network may be achieved. One type of non-hydrolytic sol-gel (NHSG) reaction is alkylhalogenide elimination. ${ }^{26}$ In this method, condensations between $\mathrm{SiCl}_{4}, \mathrm{AlCl}_{3}, \mathrm{Al}\left(\mathrm{O}^{\mathrm{i}} \mathrm{Pr}\right)_{3}$, and $\mathrm{Si}\left(\mathrm{O}^{\mathrm{i}} \mathrm{Pr}\right)_{4}$ in ethers or $\mathrm{CH}_{2} \mathrm{Cl}_{2}$ provide monolithic homogeneous aluminosilicate gels ${ }^{27}$ (Scheme 1).

This non-hydrolytic sol-gel technique has also been applied to the preparation of highly active mesoporous metathesis catalysts $\mathrm{MoO}_{3}-\mathrm{SiO}_{2}-\mathrm{Al}_{2} \mathrm{O}_{3}{ }^{28}$ and $\mathrm{Re}_{2} \mathrm{O}_{7}-\mathrm{SiO}_{2}-\mathrm{Al}_{2} \mathrm{O}_{3} \cdot{ }^{29}$ Mullite precursor gel synthesis was described from $\mathrm{AlCl}_{3}$ and TEOS in $\mathrm{Et}_{2} \mathrm{O}$ and $\mathrm{CCl}_{4}$ in an autoclave at $110{ }^{\circ} \mathrm{C}^{30}$

Catalytic efficiency of aluminosilicates was determined by a variety of test reactions. Kim reported Friedel-Crafts acylation of bulky aromatic compounds in MFI zeolite nanosponge, ${ }^{31}$ Neves $^{32}$ used mesoporous aluminosilicates with acid sites for conversion of furfuryl alcohol to ethyl levulinate and Robinson described the alcoholysis and aminolysis of styrene oxide promoted by mesoporous aluminosilicate catalysts. ${ }^{33,34}$

We have recently reported that non-hydrolytic acetamide elimination $^{35}$ can be successfully used for the synthesis of mesoporous titanium silicate ${ }^{36}$ and zirconium silicate materials. ${ }^{37}$ In contrast to conventional hydrolysis-based routes for

$$
\begin{aligned}
& \mathrm{AlCl}_{3}+\mathrm{Al}\left(\mathrm{O}^{i} \mathrm{Pr}\right)_{3}+\mathrm{SiCl}_{4}+\mathrm{Si}\left(\mathrm{O}^{i} \mathrm{Pr}\right)_{4} \underset{110^{\circ} \mathrm{C}, 13 \mathrm{~h}}{\stackrel{\mathrm{Et}_{2} \mathrm{O} / \mathrm{CCl}_{4}}{\longrightarrow}} \text { Al-O-Si Monolithic Gel }+{ }^{i} \mathrm{PrCl} \\
& \mathrm{AlCl}_{3}+\mathrm{SiCl}_{4}+{ }^{i} \mathrm{Pr}_{2} \mathrm{O} \underset{110^{\circ} \mathrm{C}, 15 \mathrm{~h}}{\stackrel{\mathrm{CH}_{2} \mathrm{Cl}_{2}}{\longrightarrow}} \text { Al-O-Si Monolithic Gel }+{ }^{i} \mathrm{PrCl}
\end{aligned}
$$

Scheme 1 Non-hydrolytic alkylhalogenide elimination. the preparation of SBA-15 and MCM-41 materials, our approach excludes hydrolytic steps and the reactions proceed only by condensation of metal amide with silicon acetate.

The work presented here introduces this novel nonhydrolytic acetamide elimination for the preparation of aluminosilicate xerogels with a high $\mathrm{Al}$ content in the framework. This effective one-pot reaction can be extended by the use of templates. With the Pluronic block copolymers we are able to obtain homogeneous xerogels which exhibit their mesoporous character even after calcination at $700{ }^{\circ} \mathrm{C}$ and convert to mullite only at $980-1000{ }^{\circ} \mathrm{C}$. We have successfully used these materials as catalysts for aminolysis ${ }^{34,38}$ and alcoholysis ${ }^{33}$ of styrene oxide and for the conversion of styrene oxide to phenylacetaldehyde. ${ }^{39}$

\section{Experimental}

\section{General procedures}

All manipulations were performed in dry nitrogen using Schlenk techniques or in an M. Braun drybox with both $\mathrm{H}_{2} \mathrm{O}$ and $\mathrm{O}_{2}$ levels below $1 \mathrm{ppm}$. $\mathrm{Al}\left(\mathrm{NMe}_{2}\right)_{3}$ is highly flammable and reacts violently with water, liberating flammable gases. It must be handled under dry inert gas at all times.

Chemicals, such as Pluronic P123 $\left(\mathrm{EO}_{20} \mathrm{PO}_{70} \mathrm{EO}_{20} M_{\mathrm{av}}=5845\right.$ $\left.\mathrm{g} \mathrm{mol}{ }^{-1}\right)$, Pluronic F127 $\left(\mathrm{EO}_{100} \mathrm{PO}_{65} \mathrm{EO}_{100} M_{\mathrm{av}}=12600 \mathrm{~g} \mathrm{~mol}^{-1}\right)$, tris(dimethylamido)aluminium $\mathrm{Al}\left(\mathrm{NMe}_{2}\right)_{3}$ (99\%), styrene oxide (97\%), aniline (97\%), methanol, and nonane, were purchased from Sigma-Aldrich. $\mathrm{Si}(\mathrm{OAc})_{4}, \mathrm{Si}_{2} \mathrm{O}(\mathrm{OAc})_{6}, \mathrm{Me}_{3} \mathrm{SiOAc}$, and $\mathrm{Si}_{2}\left(\mathrm{CH}_{2}\right)_{2}(\mathrm{OAc})_{6}$ were synthesized according to the published procedures. ${ }^{40}$ Toluene, methanol, and isopropanol were dried by standard methods and distilled before use. Pluronic P123 and $\mathrm{F} 127$ were dried under vacuum at $60{ }^{\circ} \mathrm{C}$, dissolved in dry toluene, and stored as 20.17 and $19.61 \mathrm{wt} \%$ solutions, respectively.

\section{Characterization}

IR spectra were recorded on a Bruker Tensor 27 FTIR spectrometer from $\mathrm{KBr}$ pellets or on a Bruker Alpha-Platinum ATR system. GC-MS measurements were performed on a mass spectrometer TSQ Quantum XLS coupled with a gas chromatograph Trace GC Ultra by Thermo Scientific. The gas chromatograph was equipped with a TS-SQC column (length $15 \mathrm{~m}$, diameter $0.25 \mathrm{~mm}$, film thickness $0.25 \mu \mathrm{m}$ ) using a temperature program: $50{ }^{\circ} \mathrm{C}(0 \mathrm{~min}), 5{ }^{\circ} \mathrm{C} \mathrm{min}^{-1}$ to $80{ }^{\circ} \mathrm{C}, 15{ }^{\circ} \mathrm{C} \mathrm{min}{ }^{-1}$ ramp to $120{ }^{\circ} \mathrm{C}, 35{ }^{\circ} \mathrm{C} \min ^{-1}$ ramp to $200{ }^{\circ} \mathrm{C}$, held at $200{ }^{\circ} \mathrm{C}$ for $0.5 \mathrm{~min}$. Split injection mode was used with the injector, interface, and detector temperatures all set to $200{ }^{\circ} \mathrm{C}$. The column pressure was $31.5 \mathrm{kPa}$ and the ionization energy was $70 \mathrm{eV}$. DIP MS measurements were performed with the temperature program $30{ }^{\circ} \mathrm{C}$ for $30 \mathrm{~s}, 50{ }^{\circ} \mathrm{C} \mathrm{min}^{-1} 30-450{ }^{\circ} \mathrm{C}$, and held at this temperature for $1 \mathrm{~min}$; the ionization energy was $44 \mathrm{eV}$. For liquid phase ${ }^{1} \mathrm{H}$ and ${ }^{13} \mathrm{C}$ NMR measurements, a Bruker Avance II DRX $300 \mathrm{MHz}$ spectrometer was used. The spectra were referenced to the residual proton or carbon resonances of benzene- $d_{6}$ (7.15 and $128.0 \mathrm{ppm}$ ) and $\mathrm{CDCl}_{3}$ (7.20 and $77.0 \mathrm{ppm}$ ). Solid state NMR spectra were measured on a Bruker Avance III $700 \mathrm{MHz}$ spectrometer with a MAS DVT 700S4 BL4 N- 
$\mathrm{P} / \mathrm{H}$ probe and on a Bruker Avance III $500 \mathrm{MHz}$ spectrometer with a MAS VTN 500SB BL4 N-P/F-H probe. Chemical shifts were referenced externally to ${ }^{29} \mathrm{Si} \delta\left[\left(\mathrm{Me}_{3} \mathrm{SiO}\right){ }_{8} \mathrm{Si}_{8} \mathrm{O}_{20}\right]: 11.72 \mathrm{ppm} ;{ }^{13} \mathrm{C}$ $\delta$ [adamantane]: $38.68 \mathrm{ppm} ;{ }^{27} \mathrm{Al} \delta\left[\left[\mathrm{Al}\left(\mathrm{H}_{2} \mathrm{O}\right)_{6}\right]^{3+}\right.$ (aq. solution)]: $0.0 \mathrm{ppm}$. High temperature PXRD diffractograms were recorded on an X'PertPRO diffractometer equipped with a $\mathrm{Co}_{\mathrm{K} \alpha} \mathrm{X}$-ray tube and a HTK 16 high-temperature chamber (Anton Paar, Graz, Austria) with a Pt holder. Samples were measured from 500 to $1250{ }^{\circ} \mathrm{C}$ in $50{ }^{\circ} \mathrm{C}$ increments. The sample was held during scanning at a constant temperature for $12 \mathrm{~min}$. Nitrogen adsorption/desorption experiments were performed at $77 \mathrm{~K}$ on a Quantachrome Autosorb-1MP porosimeter. Prior to the measurements, the samples were degassed at $100{ }^{\circ} \mathrm{C}$ for at least $24 \mathrm{~h}$ until the outgas rate was less than $0.4 \mathrm{~Pa} \mathrm{~min}^{-1}$. The adsorption-desorption isotherms were measured for each sample at least three times. The specific surface areas (SA), total pore volumes $\left(V_{\text {tot }}\right.$ at $\left.p / p_{0}=0.98\right)$ and average pore size $(d)$ were determined by volumetric techniques ${ }^{\mathbf{4 1 , 4 2}}$ and analyzed by the multipoint BET method using at least five data points. The valid pressure ranges were established by the Rouquerol transform and equivalent BET surface areas were calculated. Pore size distributions were calculated by the NLDFT method from the adsorption branch of the isotherms with the use of a nitrogenon-silica kernel. Thermal analysis (TG/DSC) was performed on a Netzsch STA 449C Jupiter apparatus in the stream of air (70 $\mathrm{cm}^{3} \mathrm{~min}^{-1}$ ) with a temperature ramp of $5^{\circ} \mathrm{C} \min ^{-1}$ to $1000{ }^{\circ} \mathrm{C}$, in a Pt crucible. Aluminium and silicon contents were determined on an ICP optical emission spectrometer iCAP 6500 Duo (Thermo, UK) equipped with a solid-state generator with a frequency of $27.12 \mathrm{MHz}$ and a maximum power input $1350 \mathrm{~W}$. The measurements of $\mathrm{Al}$ were performed at 167.0, 308.2, and $309.2 \mathrm{~nm}$. For Si analysis, wavelengths 212.4 and $251.6 \mathrm{~nm}$ were used. Transmission electron microscopy (TEM) images were obtained from a JEOL JEM 3010 microscope operated at $300 \mathrm{kV}$ ( $\mathrm{LaB}_{6}$ cathode, point resolution $1.7 \AA$ ) with an Oxford Instruments Energy Dispersive X-ray (EDX) detector attached. SAXS measurements were performed on a Rigaku BioSAXS 1000 system at wavelength of $1.5408 \AA$ with a PILATUS 100K detector, Dectris Lts. Scattering curves were analyzed by ATSAS software package. Studies of surface acidity were performed on aircalcined xerogels. Xerogels (ca. $50 \mathrm{mg}$ ) were dried before adsorption under vacuum $\left(1 \mathrm{~h}, 115^{\circ} \mathrm{C}\right)$. Then, the samples were exposed for $30 \mathrm{~min}$ to pyridine vapors under its autogenous pressure at $25^{\circ} \mathrm{C}$. After adsorption, samples were dried at room temperature under vacuum for $2 \mathrm{~h}$. Adsorbed pyridine was characterized by the IR technique.

The single-crystal X-ray diffraction data were collected at 120 $\mathrm{K}$ using Rigaku diffraction system (MicroMax007HF DW rotating anode source with multilayer optic, partial $\chi$ axis goniometer, Saturn 724+ HG detector and Cryostream cooling device). Molybdenum $\mathrm{K}_{\alpha}$ radiation $(\lambda=0.71075 \AA$ ) was used. CrystalClear (Rigaku 2014) and CrysAlisPro (Agilent Technologies 2013) software packages were used for data collection and data reduction. The structure was solved using SHELXT ${ }^{43}$ program and refined (full matrix least-squares refinement on $F^{2}$ ) using $S H E L X L$ program. Both symmetrically independent cation fragments were disordered. One $\mathrm{Me}_{3} \mathrm{Si}$-moiety of one

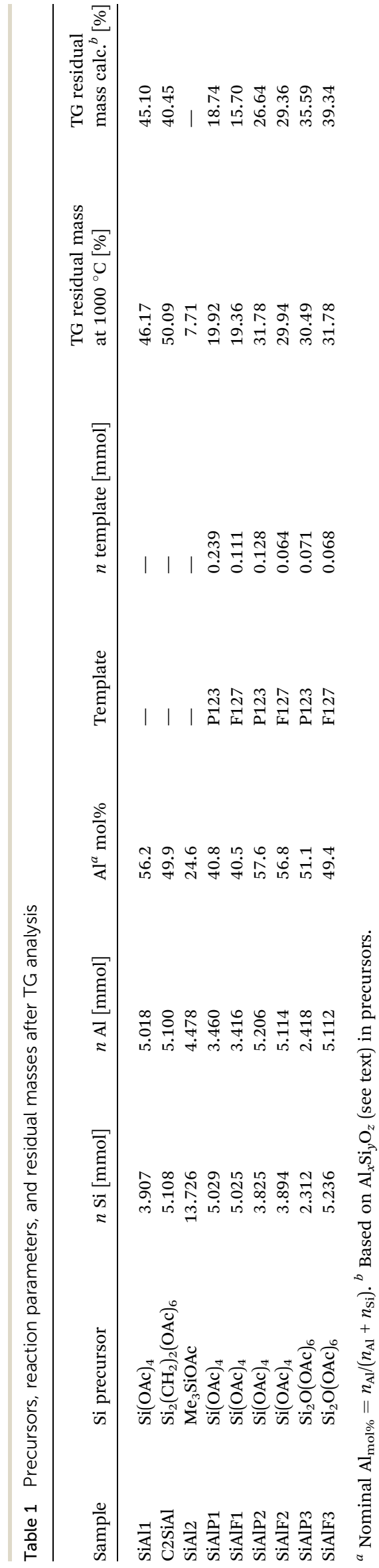


anionic fragment was also refined as disordered. Disordered fragments were treated by geometrical similarity restraints and by ADP restraints. All non-hydrogen atoms were refined anisotropically. All hydrogen atoms (of methyl and hydroxyl groups) were placed at calculated positions and refined as riding and rotating, with their $U_{\text {iso }}$ set to $1.5 U_{\text {eq }}$ of carrier atom.

In reactions without a template, the yield of the product as well as the mass of starting precursors were precisely weighed to allow gravimetric estimation of the degree of condensation, $\mathrm{DC}=100\left(n_{\text {total }}-n_{\text {residual }}\right) / n_{\text {total }}$, where $n_{\text {total }}$ is the molar amount of organic groups in the starting materials and $n_{\text {residual }}$ is molar amount of residual organic groups in the xerogel based on the difference between theoretical and experimental yields. As the condensation reactions were never quantitative, the degree of condensation represents the relative difference between the maximum theoretical loss of $\mathrm{Me}_{2} \mathrm{NC}(\mathrm{O}) \mathrm{CH}_{3}$ (eqn (1)) in comparison to what is experimentally observed. This difference also defines the number of acetoxy groups on silicon and dimethylamido groups on aluminium that are left in the matrix.

\section{Aluminosilicate xerogel prepared without template SiAl1 (eqn} (1))

$\mathrm{Al}\left(\mathrm{NMe}_{2}\right)_{3}(0.799 \mathrm{~g} ; 5.02 \mathrm{mmol})$ dissolved in $15 \mathrm{~cm}^{3}$ of dry toluene was added dropwise by a syringe to a stirred solution of $\mathrm{Si}(\mathrm{OAc})_{4}(1.033 \mathrm{~g} ; 3.907 \mathrm{mmol})$ in $15 \mathrm{~cm}^{3}$ of dry toluene at $80^{\circ} \mathrm{C}$. After the addition, a yellow gel formed. The reaction mixture was heated to $80{ }^{\circ} \mathrm{C}$ for 7 days, after which the volatile byproducts were separated under vacuum and the yellow powder was dried under vacuum for $24 \mathrm{~h}$. Yield $1.098 \mathrm{~g}$, theor. $0.494 \mathrm{~g} ; \mathrm{DC}=56 \%$.

Identification of volatile by-products. ${ }^{1} \mathrm{H}$ NMR: $(300 \mathrm{MHz}$, $\left.\mathrm{CDCl}_{3}\right) \delta(\mathrm{ppm}) 1.95\left(\mathrm{~s}, \mathrm{CH}_{3} \mathrm{C}(\mathrm{O})\right), 2.68\left(\mathrm{~s}, \mathrm{NCH}_{3}\right), 2.85\left(\mathrm{~s}, \mathrm{NCH}_{3}\right)$. GS-MS: $0.49 \mathrm{~min}(N, N$-dimethylamine) $\mathrm{m} / z=45,28 ; 1.92 \mathrm{~min}$ ( $N, N$-dimethylacetamide) $\mathrm{m} / z=87,72,44$.

Characterization of xerogel. IR spectra $\left(\mathrm{KBr}, \mathrm{cm}^{-1}\right): 443 \mathrm{w}$ $(\delta \mathrm{C}-\mathrm{N}-\mathrm{C}), 592 \mathrm{w}, 634 \mathrm{w}, 693 \mathrm{~m}\left(\mathrm{AlO}_{6}\right), 769 \mathrm{w}\left(\mathrm{AlO}_{4}\right), 801 \mathrm{w}$ $\left(\nu_{\text {sym }} \mathrm{Si}-\mathrm{O}-\mathrm{Si}\right), 1012$ vs $\left(\nu_{\text {as }} \mathrm{Si}-\mathrm{O}-\mathrm{Si} / \mathrm{Si}-\mathrm{O}-\mathrm{Al}\right), 1186 \mathrm{w}\left(\nu \mathrm{NCH}_{3}\right)$, $1265 \mathrm{w}(\nu \mathrm{C}-\mathrm{N}-\mathrm{C}), 1386 \mathrm{~m}\left(\delta \mathrm{CH}_{3}\right), 1412 \mathrm{~m}, 1468 \mathrm{~m}(\nu \mathrm{COO}), 1510$ $\mathrm{m}(\nu \mathrm{C}=\mathrm{O}), 1596 \mathrm{vs}(\nu \mathrm{COO}), 1536$ vs $(\nu \mathrm{COO}), 1718 \mathrm{vw}(\nu \mathrm{COO})$, $2799 \mathrm{vw}\left(\nu \mathrm{CH}_{3}\right), 2930 \mathrm{w}\left(\nu \mathrm{CH}_{3}\right), 3410 \mathrm{vw}(\nu \mathrm{NH})$.

NMR: ${ }^{13} \mathrm{C}$ CPMAS (SiAl1, ppm) $\delta 21.9\left(\mathrm{CH}_{3} \mathrm{C}(\mathrm{O})\right.$ - bidentate), $24.1\left(\mathrm{CH}_{3} \mathrm{C}(\mathrm{O})\right.$ - monodentate $), 33.4,35.3\left(\mathrm{CH}_{3} \mathrm{~N}\right), 38.2\left(\mathrm{CH}_{3} \mathrm{~N}\right)$, 170.7 ( $\mathrm{CH}_{3} \mathrm{C}(\mathrm{O})$ - monodentate $), 179.4\left(\mathrm{CH}_{3} \mathrm{C}(\mathrm{O})\right.$ - bidentate $) ;{ }^{29} \mathrm{Si}$ CPMAS (ppm) $\delta-89 ;{ }^{27} \mathrm{Al}$ MAS $(\mathrm{ppm}) \delta 0\left(\mathrm{Al}^{\mathrm{VI}}=6\right.$-coordinated $\mathrm{Al}), 29\left(\mathrm{Al}^{\mathrm{V}}=5\right.$-coordinated $\left.\mathrm{Al}\right), 54\left(\mathrm{Al}^{\mathrm{IV}}=4\right.$-coordinated $\left.\mathrm{Al}\right)$.

TG/DSC (air, $5{ }^{\circ} \mathrm{C} \mathrm{min}^{-1}$ ) weight loss at $1000{ }^{\circ} \mathrm{C} 53.83 \%$.

BET: $\mathrm{SA}=607 \mathrm{~m}^{2} \mathrm{~g}^{-1}, C=146, V_{\text {tot }}=0.35 \mathrm{~cm}^{3} \mathrm{~g}^{-1}, d=2.4 \mathrm{~nm}$.

Aluminosilicate xerogel C2SiAl with $\mathrm{Si}_{2}\left(\mathrm{CH}_{2}\right)_{2}(\mathrm{OAc})_{6}$ precursor was prepared with the same procedure and under same conditions as in the case of SiAl1 xerogel. See Table 1.

\section{Aluminosilicate xerogel prepared with Pluronic F127 template SiAlF2 (eqn (1))}

$\mathrm{Al}\left(\mathrm{NMe}_{2}\right)_{3}(0.814 \mathrm{~g} ; 5.11 \mathrm{mmol})$ dissolved in $25 \mathrm{~cm}^{3}$ of the dry toluene was added dropwise by a syringe to a stirred solution of $\mathrm{Si}(\mathrm{OAc})_{4}$ (1.029 g; $\left.3.894 \mathrm{mmol}\right)$ and Pluronic F127 (0.800 g) in dry toluene $\left(25 \mathrm{~cm}^{3}\right)$ at $80{ }^{\circ} \mathrm{C}$. After the addition, the mixture color changed to light yellow and a gel formed. The reaction mixture was heated to $80^{\circ} \mathrm{C}$ for $12 \mathrm{~h}$ forming a transparent light yellow stiff gel. After 7 days of aging at this temperature, the reaction was stopped, volatile byproducts were separated in vacuo and the yellow-orange solid product was dried under vacuum for $24 \mathrm{~h}$. Yield $1.689 \mathrm{~g}$, theor. $0.496 \mathrm{~g}$.

Identification of volatile by-products. GC-MS: $1.80 \mathrm{~min}(\mathrm{~N}, \mathrm{~N}$ dimethylacetamide) $m / z=87,72,44$.

Characterization of xerogel. IR spectra (ATR, $\left.\mathrm{cm}^{-1}\right): 425 \mathrm{vw}$ $(\delta \mathrm{C}-\mathrm{N}-\mathrm{C}), 627 \mathrm{w}, 689 \mathrm{w}\left(\mathrm{AlO}_{6}\right), 766 \mathrm{w}\left(\mathrm{AlO}_{4}\right), 860 \mathrm{w}(\mathrm{CH}), 972 \mathrm{~s}$, 996 vs $(\nu \mathrm{Si}-\mathrm{O}-\mathrm{Al}), 1027$ vs $(\nu \mathrm{Si}-\mathrm{O}-\mathrm{Si}), 1034 \mathrm{vs}(\delta \mathrm{C}-\mathrm{O}-\mathrm{C}), 1253 \mathrm{w}$ $(\nu \mathrm{C}-\mathrm{N}-\mathrm{C}), 1300 \mathrm{w}, 1380 \mathrm{~m}\left(\delta \mathrm{CH}_{3}\right), 1465 \mathrm{~m}(\nu \mathrm{COO}), 1516 \mathrm{~m}$ $(\nu \mathrm{C}=\mathrm{O}), 1586 \mathrm{~s}(\nu \mathrm{COO}), 2867 \mathrm{~m}(\nu \mathrm{CH})$.

NMR: ${ }^{13} \mathrm{C}$ CPMAS (SiAlF2, ppm) $\delta 26.9\left(\mathrm{CH}_{3} \mathrm{C}(\mathrm{O})\right), 40.7$ $\left(\mathrm{CH}_{3} \mathrm{~N}\right), 74.1\left(\mathrm{CH}_{2} \mathrm{O}\right), 79(\mathrm{CHO}), 173.3\left(\mathrm{CH}_{3} \mathrm{C}(\mathrm{O})-\right.$ monodentate), $184.6\left(\mathrm{CH}_{3} \mathrm{C}(\mathrm{O})\right.$ - bidentate); ${ }^{29} \mathrm{Si}$ CPMAS (SiAlF2, ppm) $\delta-87 ;{ }^{27} \mathrm{Al}$ MAS (SiAlF2, ppm) $\delta 2\left(\mathrm{Al}^{\mathrm{VI}}\right), 32\left(\mathrm{Al}^{\mathrm{V}}\right), 61\left(\mathrm{Al}^{\mathrm{IV}}\right)$.

TG/DSC: (air, $5{ }^{\circ} \mathrm{C} \mathrm{min}^{-1}$ ) weight loss at $1000{ }^{\circ} \mathrm{C} 70.06 \%$.

Portions of dried xerogel were calcined in a tube furnace under air at 500 and $700{ }^{\circ} \mathrm{C}$ for $3 \mathrm{~h}$.

BET: (sample calcined at $500{ }^{\circ} \mathrm{C}$ ) SA $=477 \mathrm{~m}^{2} \mathrm{~g}^{-1}, C=54$, $V_{\text {tot }}=0.53 \mathrm{~cm}^{3} \mathrm{~g}^{-1}, d=5.9 \mathrm{~nm}$.

ICP OES (sample calcined at $500{ }^{\circ} \mathrm{C}$ ) wt\%: Al $25.34 \pm 0.04, \mathrm{Si}$ $18.98 \pm 0.01$.

Hydrothermal stability was studied after calcination at $500{ }^{\circ} \mathrm{C}$. The xerogel was kept in refluxing water for 24 hours. Then, water was evaporated and the sample was dried under vacuum at $100{ }^{\circ} \mathrm{C}$. Changes in the xerogel porosity and structure were studied by $\mathrm{N}_{2}$ porosimetry and MAS NMR spectroscopy.

Calcined samples are labeled with a number corresponding to the particular calcination temperature, e.g. SiAlF1-500, watertreated samples are labeled with $\mathrm{H}$, e.g. SiAlF2-500H.

Reactions with the P123 template were carried out under the same conditions as in the case of F127. Aluminosilicate xerogels

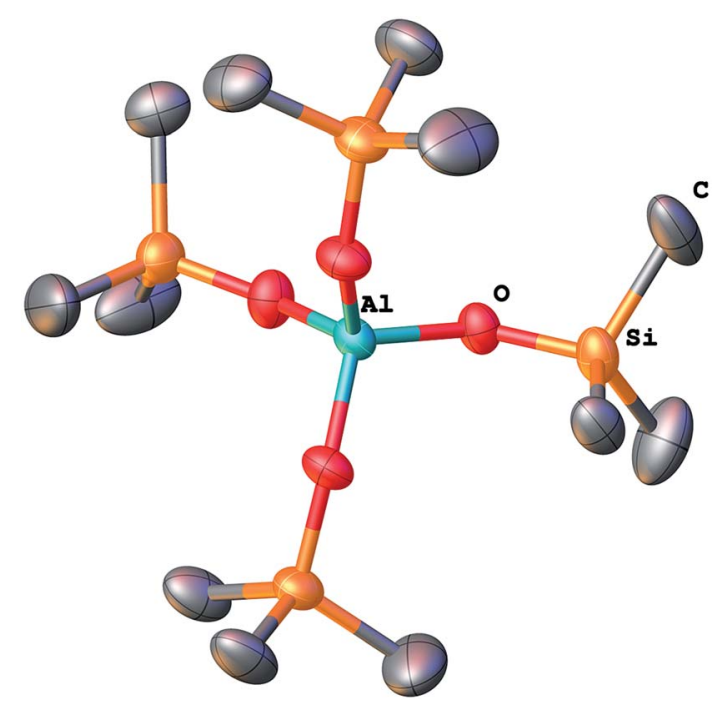

Fig. 1 Tetrahedral tetrakis(trimethylsilyloxy)aluminate anion of compound 1. 
from $\mathrm{Si}_{2} \mathrm{O}(\mathrm{OAc})_{6}$ precursor were prepared according to same protocol as in the case of SiAlF2 sample. For details see the Table 1.

\section{Condensation reaction between $\mathrm{Me}_{3}$ SiOAc and $\mathrm{Al}\left(\mathrm{NMe}_{2}\right)_{3}$}

A model condensation reaction between $\mathrm{Me}_{3} \mathrm{SiOAc}$ and $\mathrm{Al}\left(\mathrm{NMe}_{2}\right)_{3}(3: 1)$ (Table 1) led to a molecular product (1) containing the $N, N$-dimethylacetimidic acid cation $[\mathrm{Me}(\mathrm{C})$ $\left.\mathrm{OHNMe}_{2}\right]^{+}$and $\left[\mathrm{Al}\left(\mathrm{OSiMe}_{3}\right)_{4}\right]^{-}$anion (Fig. 1 and $\left.1 \mathrm{~S} \dagger\right)$. Dimethylacetamide, hexamethyldisiloxane, and small amount of dimethylamine were observed by GC-MS among the volatiles. The colorless crystalline product sublimed from the dark orange viscous mass on the walls of a Schlenk flask. These crystals (292 mg, 14\%) were separated in glove box and analyzed by single crystal X-ray diffraction analysis.

Characterization of $1 .{ }^{27} \mathrm{Al} \mathrm{NMR}\left(\mathrm{CDCl}_{3}, \mathrm{ppm}\right) \delta 59 \mathrm{ppm}$ $\left(\mathrm{AlO}_{4}\right)$.

EI-MS $(\mathrm{m} / \mathrm{z}): 589\left[\mathrm{Al}_{2}\left(\mathrm{OSiMe}_{3}\right)_{6} \mathrm{H}\right]^{+}(10 \%) ; 574\left[\mathrm{Al}_{2}\left(\mathrm{OSiMe}_{3}\right)_{5^{-}}\right.$ $\left.\mathrm{OSiMe}_{2} \mathrm{H}\right]^{+}(100 \%) ; 485\left[\mathrm{Al}_{2}\left(\mathrm{OSiMe}_{3}\right)_{4} \mathrm{OSiMe}_{2} \mathrm{H}\right]^{+}(20 \%) ; 411$ $\left[\mathrm{Al}_{2}\left(\mathrm{OSiMe}_{3}\right)_{4} \mathrm{H}\right]^{+}(50 \%)$.

\section{Catalytic reactions}

Aminolysis and alcoholysis reactions of styrene oxide ex,34,38,44 $^{\mathbf{3}}$ were performed in a $25 \mathrm{~cm}^{3}$ round-bottomed Schlenk flask connected to a $\mathrm{N}_{2}$ source. Calcined $\left(500{ }^{\circ} \mathrm{C}\right)$ aluminosilicate xerogels were degassed before the reactions under vacuum at $100{ }^{\circ} \mathrm{C}$ for $20 \mathrm{~min}$. The reaction mixture consisted of catalyst (25 $\mathrm{mg})$, dry toluene $\left(5 \mathrm{~cm}^{3}\right)$, styrene oxide $\left(0.587 \mathrm{~cm}^{3}\right.$, $5.00 \mathrm{mmol})$, and aniline $\left(0.456 \mathrm{~cm}^{3}, 5.00 \mathrm{mmol}\right)$ or methanol $\left(0.202 \mathrm{~cm}^{3}, 5.00 \mathrm{mmol}\right)$ in the case of aminolysis and alcoholysis, respectively. A blank reaction was performed without a catalyst. The reaction mixture was heated at $50{ }^{\circ} \mathrm{C}$. Catalytic products were quantified by GC-MS and ${ }^{1} \mathrm{H}$ NMR spectroscopy after $10 \mathrm{~min}$ and $1 \mathrm{~h}$. The reusability of catalyst was studied after washing the used catalyst with $\mathrm{CH}_{2} \mathrm{Cl}_{2}$ and toluene and degassing under vacuum at $115{ }^{\circ} \mathrm{C}$. We found that reused catalyst is still active. To investigate Al leaching, $30 \mathrm{mg}$ of the catalyst was refluxed in $15 \mathrm{~cm}^{3}$ of 2-propanol for $4 \mathrm{~h}$. After centrifugation and filtering off the catalyst powder, the filtrate was tested for the presence of $\mathrm{Al}$ species by ICP-OES.

\section{Results and discussion}

Aluminosilicate xerogels were synthesized by a novel acetamide elimination reaction according to eqn (1)-(3) from $\mathrm{Si}(\mathrm{OAc})_{4}$ (or bridged acetoxysilanes) and $\mathrm{Al}\left(\mathrm{NMe}_{2}\right)_{3}$ precursors in dry toluene under $\mathrm{N}_{2}$ atmosphere.

$$
\begin{gathered}
3 \mathrm{Si}(\mathrm{OAc})_{4}+4 \mathrm{Al}\left(\mathrm{NMe}_{2}\right)_{3} \rightarrow \mathrm{Al}_{4} \mathrm{Si}_{3} \mathrm{O}_{12}+12 \mathrm{Me}_{2} \mathrm{NC}(\mathrm{O}) \mathrm{CH}_{3} \\
(\mathrm{AcO})_{3} \mathrm{SiOSi}(\mathrm{OAc})_{3}+2 \mathrm{Al}\left(\mathrm{NMe}_{2}\right)_{3} \rightarrow \\
\mathrm{Al}_{2} \mathrm{Si}_{2} \mathrm{O}_{7}+6 \mathrm{Me}_{2} \mathrm{NC}(\mathrm{O}) \mathrm{CH}_{3} \\
\left.(\mathrm{AcO})_{3} \mathrm{Si}-\left(\mathrm{CH}_{2}\right)_{2}-\mathrm{Si}(\mathrm{OAc})_{3}+2 \mathrm{Al}_{(} \mathrm{NMe}_{2}\right)_{3} \rightarrow \\
\mathrm{Al}_{2} \mathrm{Si}_{2}\left(\mathrm{CH}_{2}\right)_{2} \mathrm{O}_{6}+6 \mathrm{Me}_{2} \mathrm{NC}(\mathrm{O}) \mathrm{CH}_{3}
\end{gathered}
$$

The reaction proceeds with the formation of $\mathrm{Si}-\mathrm{O}-\mathrm{Al}$ network and release of dimethylacetamide which was confirmed by GC-MS (Fig. 2S $\dagger$ ) and ${ }^{1} \mathrm{H}$ NMR analysis of volatiles separated from the reaction mixture. In the case of the reaction with excess $\mathrm{Si}(\mathrm{OAc})_{4}$, a small amount of acetic acid was observed in GC-MS.

Hexaacetoxydisiloxane $(\mathrm{AcO})_{3} \mathrm{SiOSi}(\mathrm{OAc})_{3}$ (eqn (2)) and bis(triacetoxysilyl)ethane $(\mathrm{AcO})_{3} \mathrm{Si}-\left(\mathrm{CH}_{2}\right)_{2}-\mathrm{Si}(\mathrm{OAc})_{3}$ (eqn (3)) were used for the modification of porosity and optimizing of the $\mathrm{Si} / \mathrm{Al}$ ratio. Eqn (1) represents a complete condensation of functional groups to $\mathrm{Si}-\mathrm{O}-\mathrm{Al}$ network and quantitative elimination of dimethylacetamide. However, under experimental conditions, the condensation is incomplete (Scheme 2), and degree of condensation (DC) for the reaction without a template was $56 \%$.

Reaction parameters are summarized in Table 1. Systems without the templates produced yellowish turbid gels which were dried under vacuum for $24 \mathrm{~h}$ to form yellow powders. With the use of templates, stiff and transparent yellow gels were obtained. These gels were dried to form yellow-orange rubbery or glassy products. Dried xerogels were afterwards calcined in a tube furnace at $500{ }^{\circ} \mathrm{C}$ for $3 \mathrm{~h}$ in air to remove the templates. The resulting yellowish powders possessed surface areas that were substantially improved and pore sizes corresponded to mesoporous region (see below).

To study the condensation, a model reaction between $\mathrm{Me}_{3} \mathrm{SiOAc}$ and $\mathrm{Al}\left(\mathrm{NMe}_{2}\right)_{3}$ was carried out. It provided molecular ionic compound $\left[\mathrm{Me}(\mathrm{C}) \mathrm{OHNMe}_{2}\right]^{+}\left[\mathrm{Al}\left(\mathrm{OSiMe}_{3}\right)_{4}\right]^{-}$(1) (Fig. 1 and 1S $\dagger)$. Crystallographic details and IR spectrum of 1 are summarized in ESI (Table 1S, Fig. 3S $\dagger$ ). A similar compound has been prepared by Chisholm from $\mathrm{Me}_{3} \mathrm{SiOH}$ and $\mathrm{Al}\left(\mathrm{NMe}_{2}\right)_{3} \cdot{ }^{45}$ This product shows that condensation between acetoxy and dimethylamido groups takes place forming $\mathrm{Si}-\mathrm{O}-\mathrm{Al}$ bonds.

IR spectra of all dried products were recorded to identify $\mathrm{Si}-\mathrm{O}-\mathrm{Al}$ heterolinkages and also the residual organic groups. Fig. 2 illustrates IR spectra of non-templated and F127 templated dried samples synthesized by NHSG reactions. The absence of $\mathrm{OH}$ bands attests to the truly non-aqueous nature of the xerogel synthesis. Vibrational bands located at 1030-1000 $\mathrm{cm}^{-1}$ are attributed to $\mathrm{Si}-\mathrm{O}-\mathrm{Si}$ and $\mathrm{Si}-\mathrm{O}-\mathrm{Al}$ bonds on the basis that introduction of $\mathrm{Si}-\mathrm{O}-\mathrm{Al}$ bonds in a $\mathrm{SiO}_{2}$ matrix shifts the absorption maxima toward the lower wavenumbers. ${ }^{46-48}$ Besides the bonds mentioned above, vibrational bands of residual organic groups were observed as well. Dimethylamido groups give rise to vibrational bands at 1250-1270, 1370-1380, 15101520 , and $2970-2980 \mathrm{~cm}^{-1} \cdot{ }^{49-51}$ Acetoxy moieties are characterized by the asymmetric and symmetric COO stretches at 15801590 and 1460-1470 $\mathrm{cm}^{-1}$, respectively. The difference between symmetric and asymmetric carboxylate vibrational bands is $120-130 \mathrm{~cm}^{-1}$ and according to Deacon-Phillips rules, this is indicative of the bidentate bridging mode on a metal center. ${ }^{52,53}$ Pluronic templates $\mathrm{P} 123$ and F127 are represented by vibrational bands of C-O-C bonds at 1090-1105 $\mathrm{cm}^{-1}$ and $\mathrm{CH}_{3}$ at $2860-2880 \mathrm{~cm}^{-1} \cdot{ }^{54}$

The thermal behavior of the prepared products was studied by TG/DSC analysis in air. Residual masses are summarized in Table 1 . These values are in an agreement with the calculated 


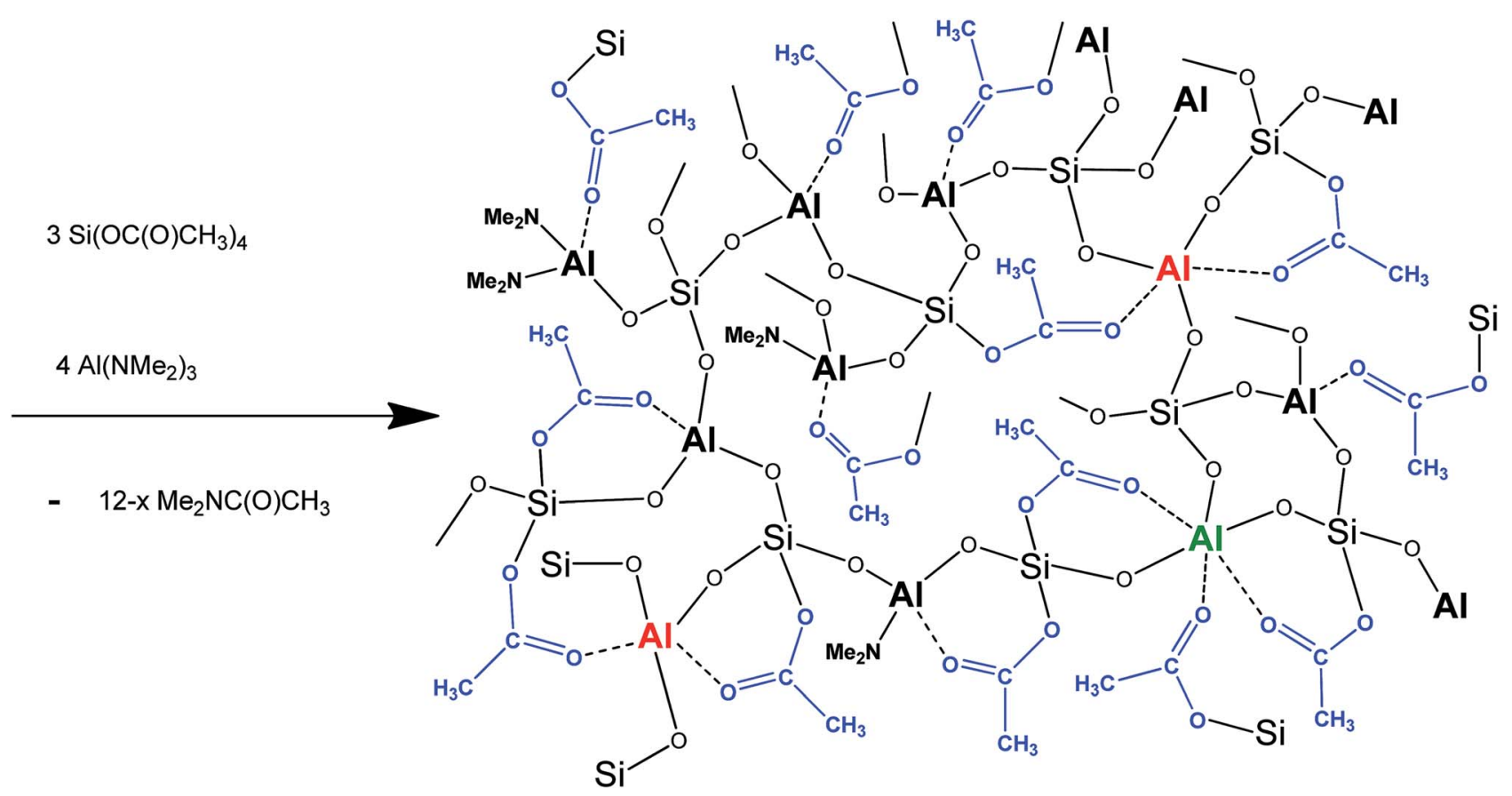

Scheme 2 Synthesis of aluminosilicate gel with four-, five-, and six-coordinate Al atoms and residual acetate and dimethylamide groups.

residual masses corresponding to aluminosilicate $\mathrm{Al}_{x} \mathrm{Si}_{y} \mathrm{O}_{z}$, where $x, y$, and $z$ represent moles of aluminium, silicon, and oxygen in precursors. For example, the TG residual mass of sample SiAlF2 (Table 1) is $29.94 \%$ while the calculated residual mass of aluminosilicate is $29.36 \%$. TG curves (Fig. $4 \mathrm{~S}^{\dagger}$ ) of xerogels synthesized without the templates display mass losses in two steps. The first mass loss is observed between $50-225^{\circ} \mathrm{C}$ (21-26\%) and the second one between $230-500{ }^{\circ} \mathrm{C}(24 \%)$. These steps are connected with oxidation of residual dimethylamido and acetoxy moieties. In the case of templated samples the highest mass losses $(52-56 \%)$ are observed between $200-450{ }^{\circ} \mathrm{C}$. Xerogels with a lower content of Al show the highest mass loss

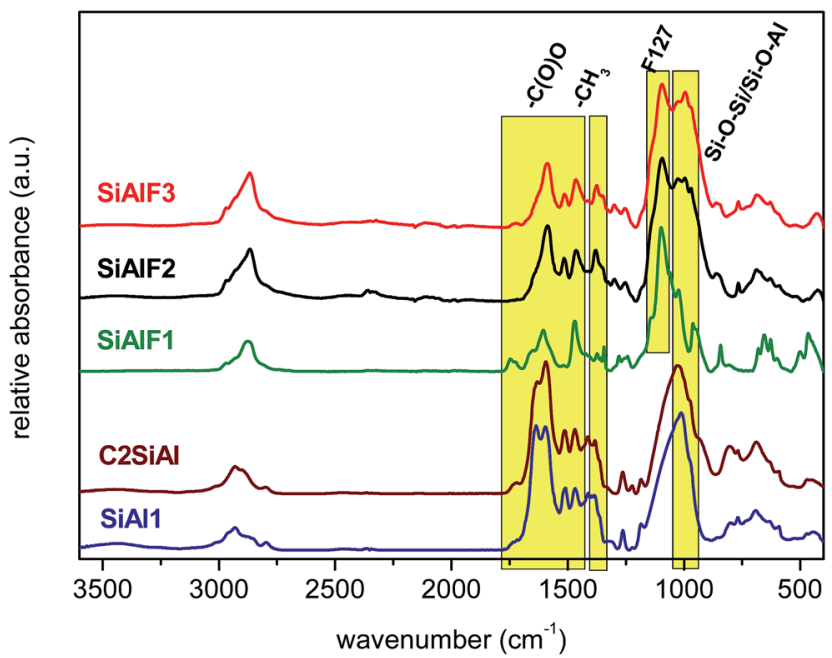

Fig. 2 IR spectra of dried aluminosilicate xerogels prepared with and without F127 template. between $125-400{ }^{\circ} \mathrm{C}(68-72 \%)$. A lower decomposition temperature than in the previous case could be explained by the oxidation of unreacted monodentate acetoxy groups bound to silicon. DSC curves of the templated samples (SiAlP2, SiAlF2) with $57-58 \mathrm{~mol} \%$ of $\mathrm{Al}$ show exothermic peaks at 995 and $985^{\circ} \mathrm{C}$ for the xerogel with F127 and P123 copolymer, respectively. This observation could be connected to crystallization of the mullite phase. ${ }^{46-48}$

Solid state NMR spectroscopy (Table 2) was employed for indepth characterization of the aluminosilicate xerogel matrix. ${ }^{13} \mathrm{C}$ CPMAS NMR spectrum of non-templated sample (SiAl1) displayed resonances of residual organic groups (Fig. 5S $\dagger$ ). Resonances at 33.1, 35.0, and $37.8 \mathrm{ppm}$ are attributed to dimethylamido groups while the acetoxy groups in bidentate and monodentate coordination are characterized by the $\mathrm{CH}_{3}$ resonances at 22.0 and $24.1 \mathrm{ppm}$, respectively. The $\mathrm{COO}$ resonances of acetate groups in unidentate and bidentate mode were observed at 170.4 and $179.5 \mathrm{ppm}$, respectively. Similar

Table 2 MAS NMR chemical shifts of aluminosilicate xerogels

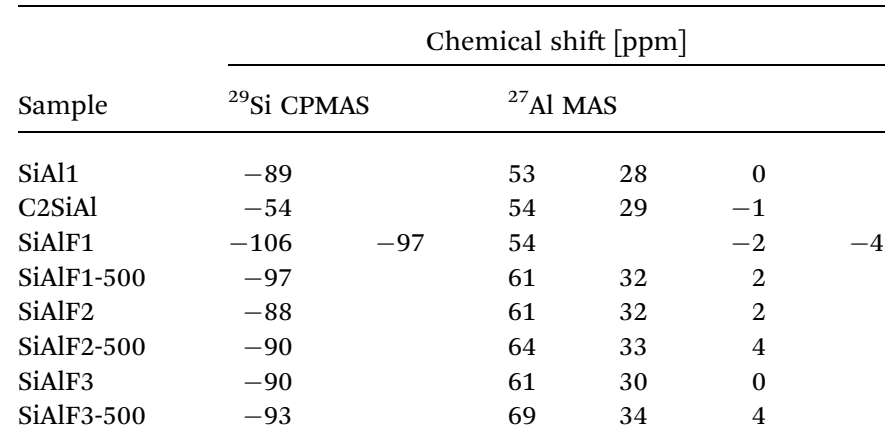




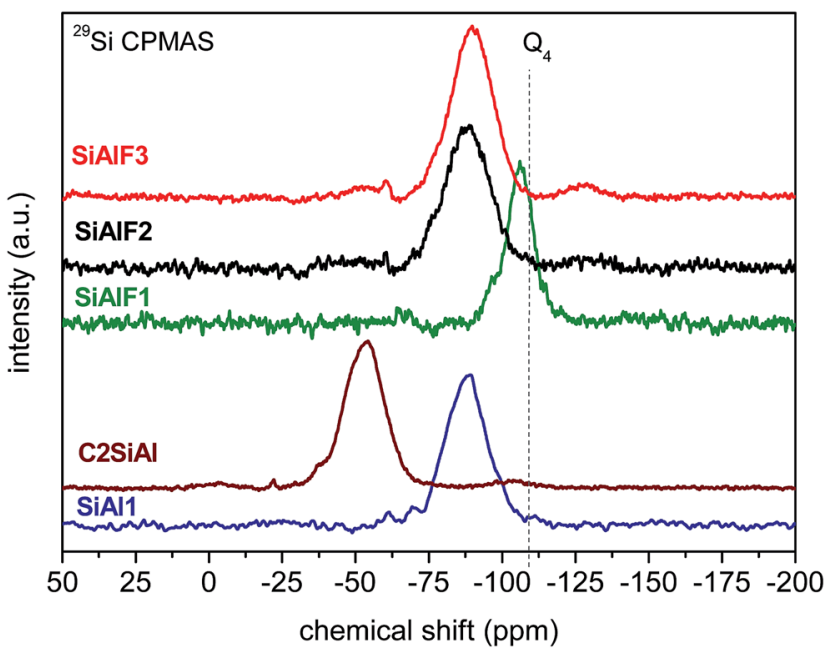

Fig. $3{ }^{29} \mathrm{Si}$ CPMAS NMR spectra of dried aluminosilicate xerogels.

resonances of residual $\mathrm{N}\left(\mathrm{CH}_{3}\right)_{2}(34.1,37.4 \mathrm{ppm}), \mathrm{CH}_{3}$ (20.7, $23.1 \mathrm{ppm})$ and $\mathrm{COO}(169.8,179.0 \mathrm{ppm})$ were observed also in the ${ }^{13} \mathrm{C}$ CPMAS spectrum of the xerogel synthesized from bis(triacetoxysilyl)ethane $(\mathrm{C} 2 \mathrm{SiAl})$. The ethylene $\left(\mathrm{CH}_{2}-\mathrm{CH}_{2}\right)$ bridge is characterized by the signal at $7.5 \mathrm{ppm}$. In the ${ }^{13} \mathrm{C}$ CPMAS NMR spectrum of F127 templated xerogel (SiAlF2, Fig. 5S $\dagger$ ), the presence of residual organic moieties was observed as well. The $\mathrm{N}\left(\mathrm{CH}_{3}\right)_{2}$ groups are seen at $40.8 \mathrm{ppm}$ and $\mathrm{CH}_{3}$ of acetoxy species are displayed at $27.3 \mathrm{ppm}$. The carboxylate function features weak signals at 173.2 and $183.2 \mathrm{ppm}$. The template carbons are represented by chemical shifts at $21.0\left(\mathrm{CH}_{3} \mathrm{CHO}\right), 74.1,76.8$, and $78.8 \mathrm{ppm}\left(\mathrm{CH}_{2} \mathrm{O}\right.$ and $\left.\mathrm{CH}_{3} \mathrm{CHO}\right) .{ }^{55}$

The ${ }^{29} \mathrm{Si}$ CPMAS NMR spectrum of non-templated sample (SiAl1) shows a broad signal with the maximum at $-89 \mathrm{ppm}$ (Fig. 3). Compared to $\mathrm{SiO}_{2}(-110 \mathrm{ppm})^{56,57}$ and $\mathrm{Si}(\mathrm{OAc})_{4}$ $(-96 \mathrm{ppm})$ a downfield shift is observed. This shift is caused by

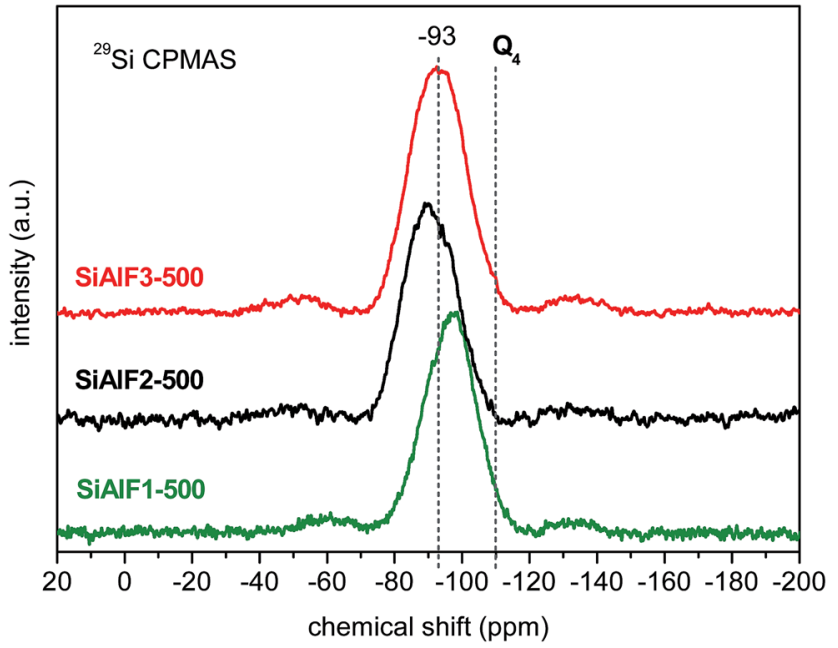

Fig. $4{ }^{29} \mathrm{Si}$ CPMAS NMR spectra of calcined $\left(500^{\circ} \mathrm{C}\right)$ aluminosilicate xerogels synthesized with F127 template.

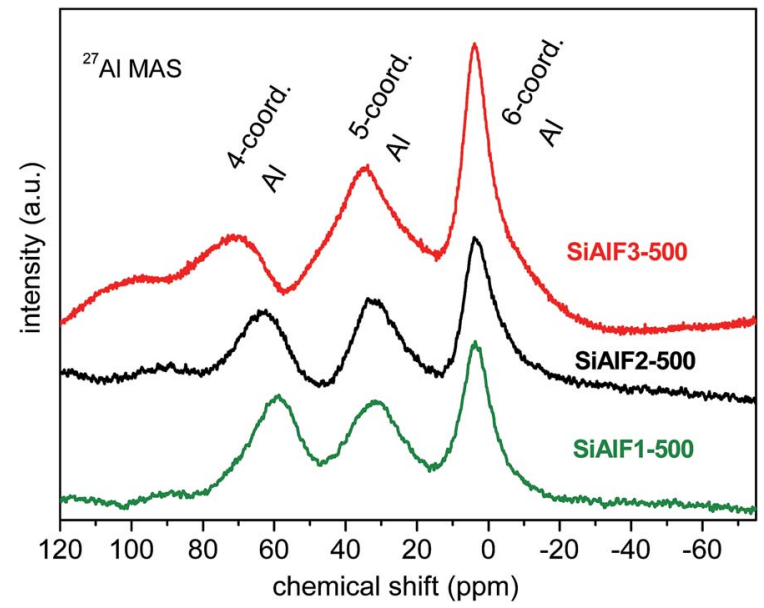

Fig. $5{ }^{27} \mathrm{Al}$ MAS NMR spectra of calcined $\left(500{ }^{\circ} \mathrm{C}\right)$ aluminosilicate xerogels synthesized with F127 template.

the presence of $\mathrm{Si}-\mathrm{O}-\mathrm{Al}$ linkages in the xerogel network. ${ }^{58-60}{ }^{29} \mathrm{Si}$ CPMAS NMR spectrum of the sample C2SiAl with ethylene $\left(\mathrm{CH}_{2}-\mathrm{CH}_{2}\right)$ bridges displays a broad signal with the maximum at -54 ppm (Fig. 3). ${ }^{29} \mathrm{Si}$ CPMAS NMR data of templated samples displays a broad signal at $-87 \mathrm{ppm}$ assigned to $\mathrm{Si}(\mathrm{OSi})(\mathrm{OAl})_{3}$ species (Fig. 3). ${ }^{\mathbf{5 8 , 5 9}}$ Similar resonances were observed after calcination at $500{ }^{\circ} \mathrm{C}$ of these templated samples (Fig. 4). The resonance at $-90 \mathrm{ppm}$ in ${ }^{29} \mathrm{Si}$ CPMAS NMR corresponds to $\mathrm{Si}(\mathrm{OSi})(\mathrm{OAl})_{3}{ }^{58,59}$ In the case of templated samples with a lower Al content (SiAlF1), ${ }^{29} \mathrm{Si}$ CPMAS displays a signal with maximum at $-106 \mathrm{ppm}$ and a shoulder at $-97 \mathrm{ppm}$. This shift could be caused by the formation of $\mathrm{Si}-\mathrm{O}-\mathrm{Si}$ bonds because of excess $\mathrm{Si}(\mathrm{OAc})_{4}$ (Fig. 3). Comparison of ${ }^{29} \mathrm{Si}$ CPMAS NMR spectra before and after calcinations for the templated samples SiAlF1, 2, 3 indicates there are not major differences (Fig. 4).

${ }^{27} \mathrm{Al}$ NMR spectra of dried xerogels provide information about the coordination number of $\mathrm{Al}$ atoms in the aluminosilicate network. ${ }^{27} \mathrm{Al}$ spectra of dried non-templated xerogels (SiAl1, $\mathrm{C} 2 \mathrm{SiAl})$ illustrate three signals attributed to 4-coordinated $\left(\mathrm{Al}^{\mathrm{IV}}\right.$, $53 \mathrm{ppm}), 5$-coordinated $\left(\mathrm{Al}^{\mathrm{V}}, 28 \mathrm{ppm}\right)$ and 6-coordinated $\left(\mathrm{Al}^{\mathrm{VI}}\right.$, 0 ppm) $\mathrm{Al}^{3,58,61}$ (Fig. $6 \mathrm{~S} \dagger$ ). ${ }^{27} \mathrm{Al}$ MAS NMR spectra of dried templated samples (SiAlF2, 3) show also the resonances for $\mathrm{Al}^{\mathrm{IV}}$ (58 ppm), $\mathrm{Al}^{\mathrm{V}}$ (31 ppm), and $\mathrm{Al}^{\mathrm{VI}}$ (2 ppm) atoms in the framework (Fig. 6S $\dagger$ ). No significant change in the ${ }^{27} \mathrm{Al}$ MAS NMR spectra of calcined templated xerogels was observed and Al signals were found at $62 \mathrm{ppm}\left(\mathrm{Al}^{\mathrm{IV}}\right), 33 \mathrm{ppm}\left(\mathrm{Al}^{\mathrm{V}}\right)$, and $4 \mathrm{ppm}\left(\mathrm{Al}^{\mathrm{VI}}\right) \cdot{ }^{58}{ }^{27} \mathrm{Al}$ MAS NMR spectrum of the sample SiAlF1 (lower Al content) displays signals for $\mathrm{Al}^{\mathrm{IV}}$ at $54 \mathrm{ppm}$ and for $\mathrm{Al}^{\mathrm{VI}}$ at -2 and $-4 \mathrm{ppm}$. After calcination of this sample, the resonances at $61 \mathrm{ppm}\left(\mathrm{Al}^{\mathrm{IV}}\right)$, $32 \mathrm{ppm}\left(\mathrm{Al}^{\mathrm{V}}\right)$, and $2 \mathrm{ppm}\left(\mathrm{Al}^{\mathrm{VI}}\right)$ were observed (Fig. 5). Chemical shifts of xerogel samples are summarized in Table 2. From these NMR data we can conclude, that the calcined xerogels still contain Si-O-Al bonds and no phase separation takes place during the calcination. The ${ }^{27} \mathrm{Al}$ NMR and EPR observations made by Chen et al. show association of five-coordinated aluminum atoms to Lewis acid sites. ${ }^{62}$ Hence, the effect of different aluminum coordination and their acid-base properties 
Table 3 Surface areas, pore volumes and pore sizes of aluminosilicate xerogels

\begin{tabular}{llllr}
\hline Sample & Template & Al mol\% & SA (BET) $\left[\mathrm{m}^{2} \mathrm{~g}^{-1}\right]$ & $V\left[\mathrm{~cm}^{3} \mathrm{~g}^{-1}\right]$ \\
\hline SiAl1 & - & 56.2 & 607 & 0.34 \\
C2SiAl & - & 49.9 & 517 & 0.38 \\
SiAlP1-500 & P123 & 42.2 & 429 & 0.37 \\
SiAlF1-500 & F127 & 40.6 & 381 & 0.37 \\
SiAlP2-500 & P123 & 59.3 & 591 & 0.53 \\
SiAlF2-500 & F127 & 58.1 & 477 & 0.53 \\
SiAlF2-700 & F127 & 58.1 & 424 & 0.41 \\
SiAlF2-500H & F127 & 58.1 & 166 & 4.9 \\
SiAlP3-500 & P123 & 54.1 & 627 & 0.28 \\
SiAlF3-500 & F127 & 50.7 & 442 & 0.55 \\
SiAlF3-500H & F127 & 50.7 & 171 & 5.9 \\
& & & & 0.4 \\
\end{tabular}

on the catalytic activity is a very interesting subject. ${ }^{27} \mathrm{Al}$ MAS spectrum of hydrothermally treated sample SiAlF2-500H shows intensity decrease of signal corresponding to 5-coordinated $\mathrm{Al}$ while the signal of 6-coordinated $\mathrm{Al}$ atoms increased (Fig. $7 \mathrm{~S}^{\dagger}$ ). This change is caused by coordination of water and -OH groups. Solid state MAS NMR spectra of the samples synthesized with the P123 template are similar and thus are not shown here.

A very important feature of these aluminosilicate xerogels is their porosity. High surface area materials with mesopores provide better catalytic efficiency for the processing of bulky organic molecules. We investigated the $\mathrm{N}_{2}$ adsorption/ desorption isotherms of the non-templated and templated samples (Table 3). The results show that xerogels synthesized without copolymer templates exhibit high surface areas after drying and feature the type-II isotherms ${ }^{63}$ (Fig. 6). Equivalent BET surface areas of xerogels prepared from $\mathrm{Si}(\mathrm{OAc})_{4}(\mathrm{SiAl1})$ and from the ethylene bridged acetoxysilane (C2SiAl, Fig. 8S $\dagger$ ) were 607 and $517 \mathrm{~m}^{2} \mathrm{~g}^{-1}$, respectively. However the pore diameters correspond to micropores in both materials. After calcination of the C2SiAl sample at $200{ }^{\circ} \mathrm{C}$, surface area decreased considerably to $36 \mathrm{~m}^{2} \mathrm{~g}^{-1}$. This change can be explained by the framework collapse while the ethylene bridging groups are oxidized.

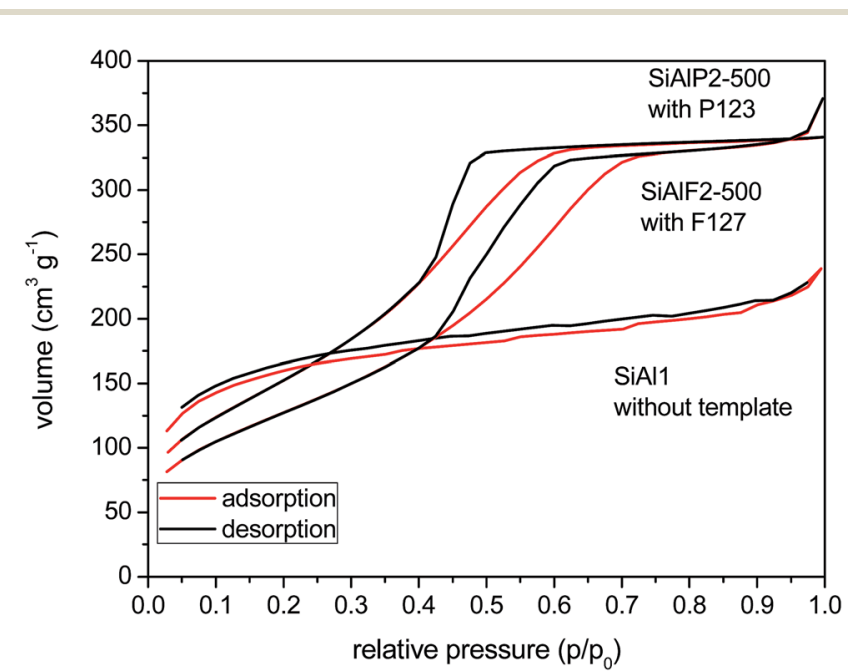

Fig. $6 \mathrm{~N}_{2}$ adsorption/desorption isotherms of aluminosilicate xerogels.
Interestingly, according to the NLDFT method, the pore diameter increased and shifted to the mesopore region $(4.8 \mathrm{~nm})$.

An improvement in morphological properties is achieved through the use of Pluronic templates (Table 3). With this approach, framework collapse during heat treatment is avoided and high surface areas are achieved after calcination at $500{ }^{\circ} \mathrm{C}$. The shape of isotherms corresponds to type IV with the H2 hysteresis consistent with significant mesopore content and narrower pore size distributions (Fig. 6 and $\left.9 S_{\dagger} \dagger\right) .{ }^{63}$ Calcined xerogel SiAlP2-500 synthesized with the P123 template containing $59.3 \mathrm{~mol} \%$ of Al exhibits surface area of $591 \mathrm{~m}^{2} \mathrm{~g}^{-1}$ and the pore volume $0.53 \mathrm{~cm}^{3} \mathrm{~g}^{-1}$. If $(\mathrm{AcO})_{3} \operatorname{SiOSi}(\mathrm{OAc})_{3}$ is used as the silicon precursor, the surface area increases to $627 \mathrm{~m}^{2} \mathrm{~g}^{-1}$. This change can be caused by better crosslinking due to a higher number of functional groups. Pore diameters of these calcined samples calculated by the NLDFT method are between 4.9 and $5.9 \mathrm{~nm}$ (Table 3). In the case of the aluminosilicates synthesized with the F127 template, surface areas in the range $381-477 \mathrm{~m}^{2} \mathrm{~g}^{-1}$ are achieved with a pore diameter of 4.9-5.9 nm (Fig. 10S $\dagger$ ). We observed that with increasing Al content the surface areas and pore volumes increased as well. Pore diameters do not change with different Si/Al ratios for P123 but

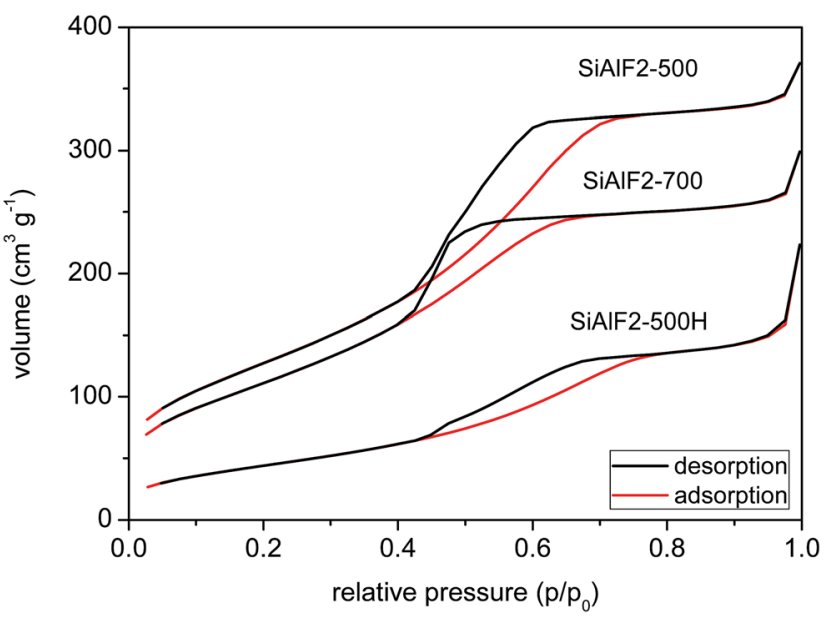

Fig. $7 \quad \mathrm{~N}_{2}$ adsorption/desorption isotherms of aluminosilicate xerogel SiAlF2 calcined at 500 (top) and $700{ }^{\circ} \mathrm{C}$ (middle). Sample SiAlF2-500H after hydrothermal treatment (bottom). 


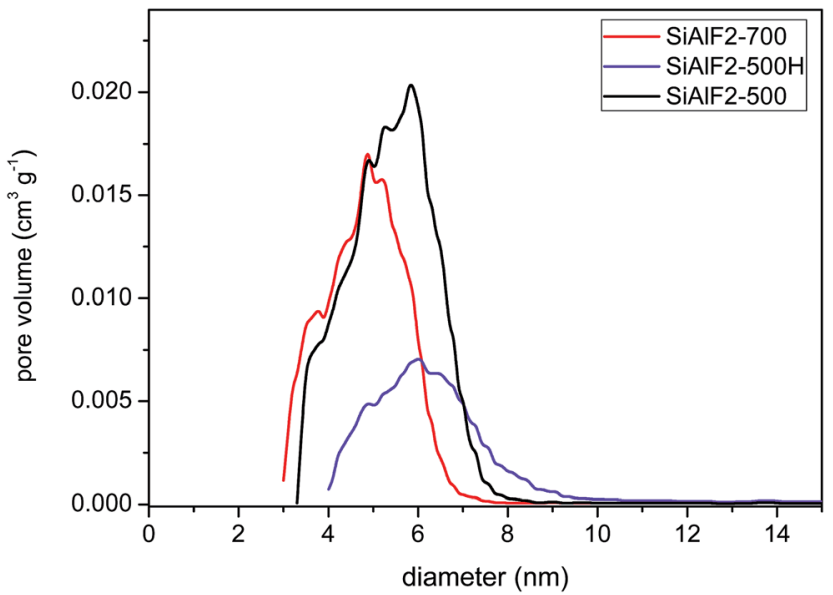

Fig. 8 NLDFT pore diameters (adsorption branch) of aluminosilicate xerogels: SiAlF2 calcined at 500 and $700{ }^{\circ} \mathrm{C}$. Sample SiAlF2-500H after hydrothermal treatment.

increased for F127. For classification of thermal stability, we calcined the sample SiAlF2 at $700{ }^{\circ} \mathrm{C}$ for $3 \mathrm{~h}$ and remeasured $\mathrm{N}_{2}$ adsorption isotherms (Fig. 7). Its surface area reached 424 $\mathrm{m}^{2} \mathrm{~g}^{-1}\left(V_{\text {tot }}=0.41 \mathrm{~cm}^{3} \mathrm{~g}^{-1}\right)$ which is about $53 \mathrm{~m}^{2} \mathrm{~g}^{-1}$ lower than in SiAlF2-500 and the pore volume and diameter decreased (Fig. 8, Table 3) and the distribution is narrower. To investigate hydrothermal stability, the sample SiAlF2-500 was exposed to boiling water for $24 \mathrm{~h}$ (Fig. 7). The surface area after this test was reduced to $166 \mathrm{~m}^{2} \mathrm{~g}^{-1}$ and pore volume to $0.28 \mathrm{~cm}^{3} \mathrm{~g}^{-1}$. The pore size distribution maximum moved to $6.1 \mathrm{~nm}$ and the mesoporous character was preserved (Fig. 8). Compared to this sample, the hydrothermally treated sample (SiAlF3-500H) synthesized with $(\mathrm{AcO})_{3} \operatorname{SiOSi}(\mathrm{OAc})_{3}$ exhibits also loss of surface area and pore volume while pore diameter increased (Table 3, Fig. 11S $\dagger$ ).

SAXS measurements of the calcined samples SiAlP2-500 and SiAlF2-500 synthesized with the P123 and F127, respectively,

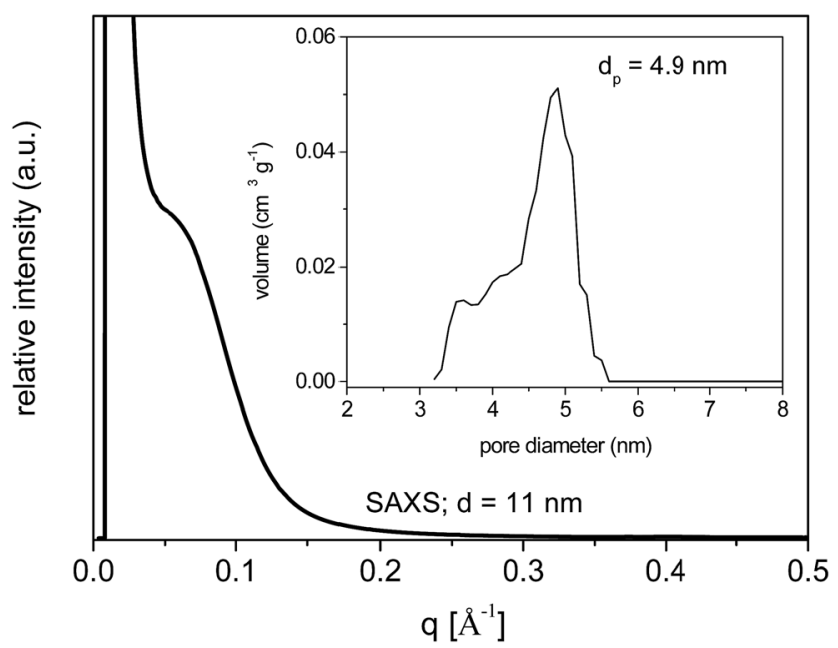

Fig. 9 SAXS pattern of calcined aluminosilicate xerogel SiAIP2-500. NLDFT pore diameter distribution (inset).
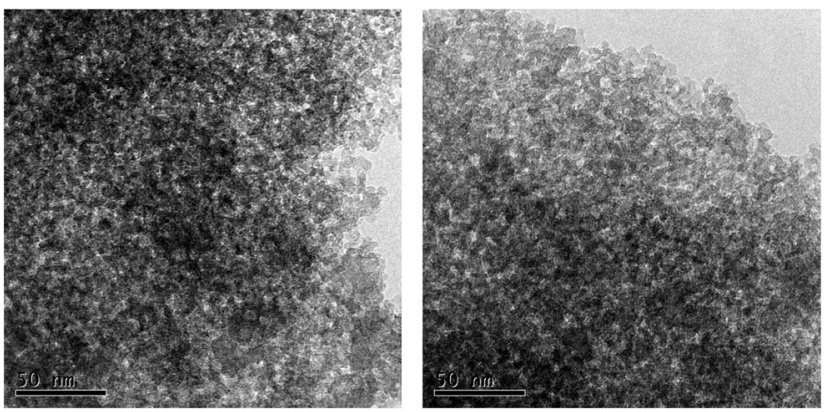

Fig. 10 TEM micrographs of SiAlF3-500 aluminosilicate with mesoporous "wormhole" like morphology.

show a weak scattering maximum at $0.42^{\circ}\left(0.06 \AA^{-1}\right)$ (Fig. 9). This behavior points to the mesoscopic ordering with the uniform pore channels in the xerogel.

The morphology of calcined mesoporous xerogels was studied by the TEM technique. The micrographs illustrate "wormhole" structure of pores (Fig. 10).

The surface acidity of the calcined xerogels was studied by pyridine adsorption. The IR spectra of the pyridine-treated samples (Fig. 11) display weak absorption bands at 1450, 1492, 1548, 1599, 1625, and $1639 \mathrm{~cm}^{-1}$. The bands corresponding to Lewis acid sites (LPy) are present at 1450 and $1625 \mathrm{~cm}^{-1}{ }^{61,64}$ Both Lewis and Brønsted acid sites are attributed to a vibrational band at $1492 \mathrm{~cm}^{-1}$. Brønsted acidic sites (BPy) are characterized by the absorption bands at 1548 and $1639 \mathrm{~cm}^{-1} \cdot{ }^{64}$ Pyridine adsorbed by hydrogen bonds (HPy) of $\equiv \mathrm{Si}-\mathrm{OH}$ moieties can be assigned to the vibrational band at $1599 \mathrm{~cm}^{-1}$. $^{61}$ These findings show that synthesized aluminosilicate xerogels exhibit surface acidity of both Lewis and Brønsted type.

High-temperature powder X-ray diffraction (HT PXRD) was used to determine the crystal phases that arise during calcination (Fig. 12S $\dagger$ ). It was found that templated samples remain amorphous up to high temperatures and then crystallize to mullite (PDF 82-1237). ${ }^{65-67}$ The xerogels SiAlP2 and SiAlF2 are

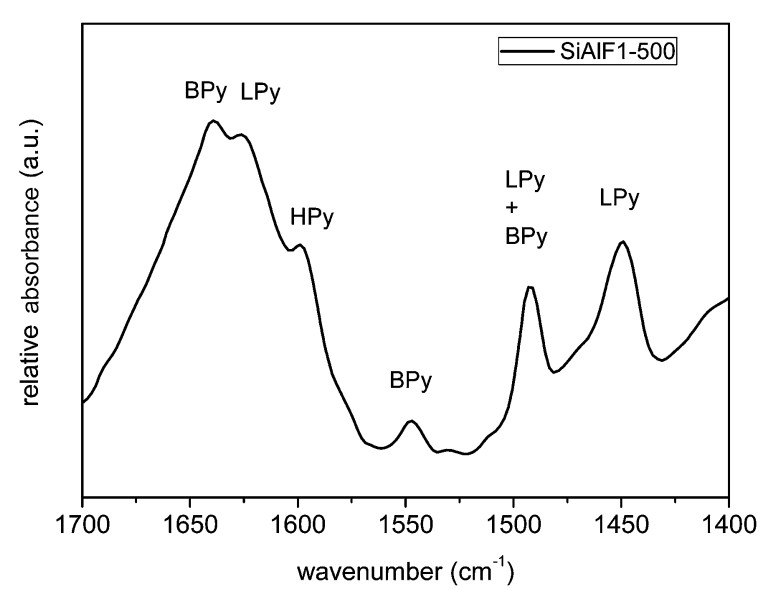

Fig. 11 IR spectra of calcined aluminosilicate xerogel (SiAlF1-500) after pyridine adsorption. 
Table 4 Aminolysis of styrene oxide. Catalytic yields and selectivities

\begin{tabular}{|c|c|c|c|c|c|c|c|}
\hline Sample & $\begin{array}{l}\mathrm{Al} \mathrm{mol} \% \\
\text { (ICP) }\end{array}$ & $\begin{array}{l}n \mathrm{Al} \text { in catal. } \\
(25 \mathrm{mg})[\mathrm{mmol}]\end{array}$ & Time [min] & Conversion [\%] & \multicolumn{2}{|c|}{ Selectivity [\%] } & TOF $^{a}$ \\
\hline & & & 60 & 79 & 95 & 5 & 25 \\
\hline \multirow[t]{2}{*}{ SiAlF1-500 } & 40.6 & 0.15 & 10 & 50 & 97 & 3 & 100 \\
\hline & & & 60 & 82 & 98 & 2 & 27 \\
\hline \multirow{2}{*}{ SiAlF3-500 } & 50.7 & 0.19 & 10 & 50 & 96 & 4 & 79 \\
\hline & & & 60 & 79 & 96 & 4 & 21 \\
\hline \multirow[t]{2}{*}{ SiAlP3-500 } & 54.1 & 0.21 & 10 & 56 & 96 & 4 & 80 \\
\hline & & & 60 & 80 & 96 & 4 & 19 \\
\hline
\end{tabular}

amorphous up to $950{ }^{\circ} \mathrm{C}$ before the diffraction lines of mullite are observed at $1000^{\circ} \mathrm{C}$ (Fig. $12 \mathrm{~S}^{\dagger}$ ). These findings correspond to exothermic effects in DSC analysis $\left(995\right.$ and $\left.985{ }^{\circ} \mathrm{C}\right)$. In the case of xerogels with a lower content of $\mathrm{Al}$, diffraction evidence for mullite appeared at $1050{ }^{\circ} \mathrm{C}$. Besides the mullite phase, crystalline $\mathrm{SiO}_{2}$ (cristobalite $\mathrm{PDF} 85-0621$ ) at $1100{ }^{\circ} \mathrm{C}$ was observed as well. The presence of cristobalite could be explained by the excess of $\mathrm{Si}(\mathrm{OAc})_{4}$ in the starting mixture which results in the phase separation during calcination. Samples synthesized with (AcO) ${ }_{3} \mathrm{SiOSi}(\mathrm{OAc})_{3}$ (SiAlF3-500 and SiAlP3-500) exhibit the mullite phase with crystallization temperature between $950-1000{ }^{\circ} \mathrm{C}$. Crystallization of mullite at $\sim 980{ }^{\circ} \mathrm{C}$ indicates the homogeneity of aluminosilicate gels at the atomic level. ${ }^{26,68,69}$ These findings show that our mesoporous aluminosilicates can be transformed to homogeneous mullite phase.

\section{Catalytic studies}

Catalytic activities of the synthesized xerogels were tested in two types of model reactions (Fig. 13S and 14S $\dagger$ ). At first, aminolysis of styrene oxide with aniline ${ }^{34,44}$ was investigated with the calcined aluminosilicate xerogel as a catalyst. The second model reaction was alcoholysis of styrene oxide with methanol. ${ }^{33}$ Catalytic yields for aminolysis are summarized in Table 4 . The blank reaction without a catalyst was performed as well and no product was obtained after $4 \mathrm{~h}$. We observed that our calcined mesoporous xerogels are efficient catalysts for aminolysis reaction of epoxides. The ${ }^{1} \mathrm{H}$ NMR spectra of the reaction mixture (in $\mathrm{C}_{6} \mathrm{D}_{6}$ ) display resonances attributed to two products: 2-phenyl-2-(phenylamino)ethanol (Ia) and 1-phenyl-2(phenylamino)ethanol (IIa) (Fig. 13S and 15S †े). These products were also confirmed by the GC-MS technique. Catalytic yields were analyzed after 10 and 60 minutes. The highest conversion was observed with the catalyst SiAlF1-500 (82\% after 1 hour). However, high catalytic efficiencies (up to 80\%) were reached in all cases (Table 4). Catalyst with a high content of Al exhibits a lower catalytic activity which could be caused by the presence of larger alumina clusters. Xerogels synthesized with $(\mathrm{AcO})_{3} \operatorname{SiOSi}(\mathrm{OAc})_{3}$ provide higher homogeneity and better dispersion of $\mathrm{Al}$ in framework and furthermore a higher catalytic activity. We also investigated recycling the catalysts in the second reaction run. The styrene oxide conversion with $7 \mathrm{mg}$ of reused xerogel (SiAlF3-500) reached 21\% after $1 \mathrm{~h}$ which represents nearly the same activity (TOF $=20)$ as the fresh catalyst. A report describing aluminosilicates as catalysts for aminolysis was published by Robinson. ${ }^{70}$ These nanoporous catalysts are prepared by conventional hydrolytic sol-gel process from TEOS and aluminium nitrate nonahydrate in the presence of cetyltrimethylammonium bromide. The comparison between these catalysts and our mesoporous aluminosilicates is presented in Table 5.

In the case of styrene oxide alcoholysis, our catalysts exhibit a lower efficiency than in aminolysis reactions. Catalytic products confirmed by GC-MS and ${ }^{1} \mathrm{H}$ NMR were (Fig. 15S and 16S $\dagger$ ) (1,2-dimethoxyethyl)-benzene (Ib) and phenylacetaldehyde (IIb) (Fig. 14S, $\uparrow$ Table 6). Catalyst SiAlF1-500 exhibits 28 and $44 \%$

Table 5 Aminolysis of styrene oxide. Comparison with other aluminosilicate catalysts synthesized by hydrolytic sol-gel

\begin{tabular}{|c|c|c|c|c|c|c|}
\hline Sample & $\mathrm{Si} / \mathrm{Al}$ & Temperature $\left[{ }^{\circ} \mathrm{C}\right]$ & Time $[\mathrm{h}]$ & $m[\mathrm{mg}]$ & Conversion [\%] & $\begin{array}{l}\text { Selectivity } \\
\text { (Ia : IIa) [\%] }\end{array}$ \\
\hline SiAlF1-500 & 1.5 & 50 & 1 & 25 & 82 & $98: 2$ \\
\hline SiAlF2-500 & 0.7 & 50 & 1 & 25 & 69 & $95: 5$ \\
\hline SiAlF3-500 & 1.0 & 50 & 1 & 25 & 80 & $96: 4$ \\
\hline AS- $(14)^{70}$ & 14 & r. t. & 6 & 50 & 37 & $95: 5$ \\
\hline AS- $(14)^{70}$ & 14 & r. t. & 24 & 50 & 53 & $95: 5$ \\
\hline AS- $(14)^{70}$ & 14 & 40 & 6 & 50 & 28 & $95: 5$ \\
\hline AlKIT-5 $(10)^{38}$ & 10 & r. t. & 0.5 & 50 & 87 & - \\
\hline
\end{tabular}


Table 6 Alcoholysis of styrene oxide. Catalytic yields and selectivities

\begin{tabular}{|c|c|c|c|c|c|c|}
\hline \multirow[b]{2}{*}{ Sample } & \multirow[b]{2}{*}{ Al mol\% (ICP) } & \multirow[b]{2}{*}{$n \mathrm{Al}$ in catal. $[\mathrm{mmol}]$} & \multirow[b]{2}{*}{ Time $[\mathrm{h}]$} & \multirow[b]{2}{*}{ Conversion $[\%]$} & \multicolumn{2}{|c|}{ Selectivity [\%] } \\
\hline & & & & & Ib & IIb \\
\hline \multirow[t]{3}{*}{ SiAlF1-500 } & 40.6 & 0.15 & 2 & 28 & 63 & 37 \\
\hline & & & 3 & 32 & 59 & 41 \\
\hline & & & 5 & 44 & 54 & 46 \\
\hline
\end{tabular}

conversion of styrene oxide after 2 and $5 \mathrm{~h}$, respectively. Selectivity for (1,2-dimethoxyethyl)-benzene after $5 \mathrm{~h}$ reached $54 \%$.

We also performed a catalytic reaction with the catalyst SiAlF1-500 where no methanol was used. In this case, phenylacetaldehyde was observed as the only product and the catalytic yield after $1 \mathrm{~h}$ was $35 \%$. A leaching test confirmed that no $\mathrm{Al}$ was released into the solution. Only $0.3 \%$ of the total aluminium amount in catalyst was found in the filtrate.

\section{Conclusions}

The non-hydrolytic sol-gel (NHSG) reactions based on acetamide elimination described here provide a very effective route to homogeneous aluminosilicate xerogels with high Al loading. This one pot reaction proceeds as polycondensation between acetoxysilanes and aluminium(III) dimethylamide and leads to the formation of Al-O-Si networks. In all cases $N, N$-dimethylacetamide was confirmed as the only reaction byproduct attesting to the absence of homocondensation reactions. $\mathrm{Al}-\mathrm{O}-\mathrm{Si}$ bonds were identified by IR spectroscopy and ${ }^{29} \mathrm{Si}$ and ${ }^{27} \mathrm{Al}$ MAS NMR spectroscopy. We observed 4-, 5-, and 6-coordinated Al atoms in the frameworks of both dried and calcined xerogels. These materials exhibit high surface areas (up to $607 \mathrm{~m}^{2} \mathrm{~g}^{-1}$ ) but are microporous. Calcination causes framework collapse and samples lose porosity. With the use of block copolymer templates such as Pluronic P123 and F127, homogeneous, stiff gels were obtained. After calcination at 500 and $700{ }^{\circ} \mathrm{C}$ mesoporous aluminosilicate materials with high surface areas ranging from 380 to $627 \mathrm{~m}^{2} \mathrm{~g}^{-1}$ with the pore diameters 4.9 (P123) and 5.9 (F127) nm were obtained. After hydrothermal treatment, the surface area decreased but mesoporous character was preserved. Calcined xerogels were investigated as catalysts for the aminolysis and alcoholysis of styrene oxide. The presence of catalytic active acidic sites (Lewis, Brønsted) was determined by pyridine adsorption. All xerogels exhibit good catalytic activity. Especially in the aminolysis model reaction, very high conversions (69-82\%) were observed.

\section{Acknowledgements}

This research has been financially supported by the Ministry of Education, Youth and Sports of the Czech Republic under the project CEITEC 2020 (LQ1601). Authors thank the project KONTAKT II LH11028, the X-ray Diffraction and Bio-SAXS Core Facility of CEITEC, L. Simonikova for ICP-OES analyses, and V. Vykoukal for the SAXS measurements.

\section{References}

1 D. S. Santilli and S. I. Zones, Catal. Lett., 1990, 7, 383-387.

2 G. F. Wan, A. J. Duan, Y. Zhang, Z. Zhao, G. Y. Jiang, D. Q. Zhang, Z. Y. Gao, J. Liu and K. H. Chung, Energy Fuels, 2009, 23, 3846-3852.

3 E. Masika and R. Mokaya, Chem. Mater., 2011, 23, 2491-2498.

4 G. A. Pozarnsky and A. V. McCormick, J. Non-Cryst. Solids, 1995, 190, 212-225.

5 J. Ren, L. Zhang and H. Eckert, J. Sol-Gel Sci. Technol., 2014, 70, 482-490.

6 C. T. Kresge, M. E. Leonowicz, W. J. Roth, J. C. Vartuli and J. S. Beck, Nature, 1992, 359, 710-712.

7 R. Mokaya and W. Jones, Chem. Commun., 1998, 1839-1840.

8 K. Wang, Y. Lin, M. A. Morris and J. D. Holmes, J. Mater. Chem., 2006, 16, 4051.

9 D. Zhao, Q. Huo, J. Feng, B. F. Chmelka and G. D. Stucky, J. Am. Chem. Soc., 1998, 120, 6024-6036.

10 A. Sakthivel, S. J. Huang, W. H. Chen, Z. H. Lan, K. H. Chen, H. P. Lin, C. Y. Mou and S. B. Liu, Adv. Funct. Mater., 2005, 15, 253-258.

11 C. Li, Y. Wang, Y. Guo, X. Liu, Y. Guo, Z. Zhang, Y. Wang and G. Lu, Chem. Mater., 2007, 19, 173-178.

$12 \mathrm{~S} . \mathrm{Li}, \mathrm{Q} . \mathrm{Xu}, \mathrm{J}$. Chen and Y. Guo, Ind. Eng. Chem. Res., 2008, 47, 8211-8217.

13 H. Liu, L. Wang, W. Feng, L. Cao, X. Gao, H. Liu and C. Xu, Ind. Eng. Chem. Res., 2013, 52, 3618-3627.

14 G. M. Kumaran, S. Garg, K. Soni, M. Kumar, L. D. Sharma, K. S. Rama Rao and G. M. Dhar, Ind. Eng. Chem. Res., 2007, 46, 4747-4754.

15 A. Vinu, D. P. Sawant, K. Ariga, M. Hartmann and S. B. Halligudi, Microporous Mesoporous Mater., 2005, 80, 195-203.

16 Q. Li, Z. Wu, B. Tu, S. S. Park, C.-S. Ha and D. Zhao, Microporous Mesoporous Mater., 2010, 135, 95-104.

17 C. Han, H. Wang, L. Zhang, R. Li, Y. Zhang, Y. Luo and X. Zheng, Adv. Powder Technol., 2011, 22, 20-25.

18 Y. Liu, W. Zhang and T. J. Pinnavaia, Angew. Chem., Int. Ed., 2001, 40, 1255-1258.

19 Y. Liu and T. J. Pinnavaia, Chem. Mater., 2002, 14, 3-5.

20 Z. Zhang, Y. Han, L. Zhu, R. Wang, Y. Yu, S. Qiu, D. Zhao and F.-S. Xiao, Angew. Chem., Int. Ed., 2001, 40, 1258-1262.

21 H. Wang, Y. Liu and T. J. Pinnavaia, J. Phys. Chem. B, 2006, 110, 4524-4526.

22 D. Trong On and S. Kaliaguine, Angew. Chem., Int. Ed., 2002, 41, 1036-1040. 
23 D. Trong On and S. Kaliaguine, J. Am. Chem. Soc., 2003, 125, 618-619.

24 H. Liu, K. Guo, X. Li, S. Liu, X. Gao, H. Liu, L. Cao, Y. Chen and C. Xu, Microporous Mesoporous Mater., 2014, 188, 108117.

25 M. Enterría, F. Suárez-García, A. Martínez-Alonso and J. M. D. Tascón, J. Alloys Compd., 2014, 583, 60-69.

26 A. Vioux, Chem. Mater., 1997, 9, 2292-2299.

27 S. Acosta, R. Corriu, D. Leclercq, P. H. Mutin and A. Vioux, J. Sol-Gel Sci. Technol., 1994, 2, 25-28.

28 D. P. Debecker, K. Bouchmella, M. Stoyanova, U. Rodemerck, E. M. Gaigneaux and P. Hubert Mutin, Catal. Sci. Technol., 2012, 2, 1157-1164.

29 K. Bouchmella, P. Hubert Mutin, M. Stoyanova, C. Poleunis, P. Eloy, U. Rodemerck, E. M. Gaigneaux and D. P. Debecker, J. Catal., 2013, 301, 233-241.

30 D. Janackovic, A. Orlovic, D. Skala, S. Drmanic, L. KosticGvozdenovic, V. Jokanovic and D. Uskokovic, Nanostruct. Mater., 1999, 12, 147-150.

31 J.-C. Kim, K. Cho, S. Lee and R. Ryoo, Catal. Today, 2015, 243, 103-108.

32 P. Neves, S. Lima, M. Pillinger, S. M. Rocha, J. Rocha and A. A. Valente, Catal. Today, 2013, 218-219, 76-84.

33 M. W. C. Robinson, R. Buckle, I. Mabbett, G. M. Grant and A. E. Graham, Tetrahedron Lett., 2007, 48, 4723-4725.

34 M. W. C. Robinson, D. A. Timms, S. M. Williams and A. E. Graham, Tetrahedron Lett., 2007, 48, 6249-6251.

35 A. Styskalik, D. Skoda, J. Pinkas and S. Mathur, J. Sol-Gel Sci. Technol., 2012, 63, 463-472.

36 D. Skoda, A. Styskalik, Z. Moravec, P. Bezdicka, C. Barnes and J. Pinkas, J. Sol-Gel Sci. Technol., 2015, 74, 810-822.

37 D. Skoda, A. Styskalik, Z. Moravec, P. Bezdicka and J. Pinkas, J. Mater. Sci., 2015, 50, 3371-3382.

38 R. Chakravarti, H. Oveisi, P. Kalita, R. R. Pal, S. B. Halligudi, M. L. Kantam and A. Vinu, Microporous Mesoporous Mater., 2009, 123, 338-344.

39 D. Barreca, M. P. Copley, A. E. Graham, J. D. Holmes, M. A. Morris, R. Seraglia, T. R. Spalding and E. Tondello, Appl. Catal., A, 2006, 304, 14-20.

40 J. Goubeau and R. Mundiel, Z. Anorg. Allg. Chem., 1953, 272, 313-325.

41 J. Rouquerol, F. Rouquerol, P. Llewellyn, G. Maurin and K. S. W. Sing, Adsorption by Powders and Porous Solids: Principles, Methodology and Applications, Elsevier Science, 2013.

42 S. Lowell, J. Shields, M. Thomas and M. Thommes, in Characterization of Porous Solids and Powders: Surface Area, Pore Size and Density, Springer Netherlands, 2004, vol. 16, ch. 5, pp. 58-81.

43 G. Sheldrick, Acta Crystallogr., Sect. A: Found. Crystallogr., 2008, 64, 112-122.
44 R. Kore, R. Srivastava and B. Satpati, ACS Catal., 2013, 3, 2891-2904.

45 M. H. Chisholm, J. C. Huffman and J. L. Wesemann, Polyhedron, 1991, 10, 1367-1372.

46 Y. Hirata, K. Sakeda, Y. Matsushita, K. Shimada and Y. Ishihara, J. Am. Ceram. Soc., 1989, 72, 995-1002.

47 E. Ruiz de Sola, F. Estevan, F. J. Torres and J. Alarcón, J. NonCryst. Solids, 2005, 351, 1202-1209.

48 C. S. Blackwell, J. Phys. Chem., 1979, 83, 3251-3257.

49 A. M. Dwivedi, S. Krimm and S. Mierson, Spectrochim. Acta, Part A, 1989, 45, 271-279.

50 G. Socrates, Infrared and Raman characteristic group frequencies : tables and charts, John Wiley \& Sons, West Sussex, 2007.

51 V. Venkata Chalapathi and K. Venkata Ramiah, Proc. Indiana Acad. Sci., 1968, 68, 109-122.

52 G. Deacon and R. Phillips, Coord. Chem. Rev., 1980, 33, 227250.

53 S. Doeuff, M. Henry, C. Sanchez and J. Livage, J. Non-Cryst. Solids, 1987, 89, 206-216.

54 Y.-l. Su, J. Wang and H.-z. Liu, Langmuir, 2002, 18, 53705374.

55 H.-M. Kao, C.-L. Chen and S.-W. Chiao, J. Chin. Chem. Soc., 2005, 52, 693-699.

56 R. Simonutti, A. Comotti, S. Bracco, A. Simonelli and P. Sozzani, Chem. Mater., 2002, 14, 3377-3381.

57 D. W. Sindorf and G. E. Maciel, J. Phys. Chem., 1982, 86, 5208-5219.

58 M. Toba, F. Mizukami, S.-i. Niwa, T. Sano, K. Maeda and H. Shoji, J. Mater. Chem., 1994, 4, 1131.

59 E. Lippmaa, M. Maegi, A. Samoson, M. Tarmak and G. Engelhardt, J. Am. Chem. Soc., 1981, 103, 4992-4996.

60 I. Jaymes, A. Douy, D. Massiot and J.-P. Coutures, J. NonCryst. Solids, 1996, 204, 125-134.

61 C. Hernandez and A. C. Pierre, Langmuir, 2000, 16, 530-536. 62 F. R. Chen, J. G. Davis and J. J. Fripiat, J. Catal., 1992, 133, 263-278.

63 M. Thommes, Chem. Ing. Tech., 2010, 82, 1059-1073.

64 M. A. Betiha, M. F. Menoufy, A. M. Al-Sabagh, H. M. A. Hassan and S. A. Mahmoud, Microporous Mesoporous Mater., 2015, 204, 15-24.

65 H. Schneider, J. Schreuer and B. Hildmann, J. Eur. Ceram. Soc., 2008, 28, 329-344.

66 S. Satoshi, C. Contreras, H. Juárez, A. Aguilera and J. Serrato, Int. J. Inorg. Mater., 2001, 3, 625-632.

67 D. M. D. D. R. Treadwell and I. A. Aksay, Chem. Mater., 1996, 8, 2056-2060.

68 A. Navrotsky, Chem. Mater., 1994, 6, 160-170.

69 F. He and W. T. Petuskey, Mater. Lett., 2009, 63, 2631-2634.

70 M. W. C. Robinson, A. M. Davies, I. Mabbett, T. E. Davies,

D. C. Apperley, S. H. Taylor and A. E. Graham, J. Mol. Catal. A: Chem., 2010, 329, 57-63. 